\title{
REIT Auditor Fees and Financial Market Transparency
}

\author{
Bartley R. Danielsen, ${ }^{\mathrm{a}}$ David M. Harrison, ${ }^{\mathrm{b}}$ Robert A. Van Ness ${ }^{\mathrm{c}}$ and Richard S. Warr ${ }^{\mathrm{a}}$ \\ ${ }^{a}$ Jenkins Graduate School of Management, North Carolina State University, Raleigh, NC \\ ${ }^{b}$ Rawls College of Business, Texas Tech University, Lubbock, TX \\ ${ }^{c}$ School of Business Administration, University of Mississippi, Oxford, MS
}

Forthcoming: Real Estate Economics 


\title{
REIT Auditor Fees and Financial Market Transparency
}

\begin{abstract}
This paper examines the relationship between over-investment in audit services, abnormal nonaudit fees paid to the auditor, and market-based measures of firm transparency. REITs provide a uniquely attractive laboratory for examining this relationship due to their tax status as passthrough entities. Since REITs must distribute $90 \%$ of their earnings as dividends, many are repeat participants in the seasoned equity market. Thus, REITs have unusually strong incentives to strive for security market transparency. We find that the capital markets reward REITs that "over-invest" in audit services with better liquidity as measured by bid-ask spreads. However, firms with abnormally high non-audit expenditures appear to be penalized with wider spreads. We infer that high non-audit fees are seen as potentially compromising auditor independence, consistent with Srinidhi and Gul (2007).
\end{abstract}




\section{Introduction}

A lengthy and sophisticated literature that uses publicly available data to predict auditor fees has developed in academic accounting journals. As one would expect, these models mostly focus on the role of financial accounting measures as fee determinants. For example, audit fees are positively correlated with accounts receivable and inventories because the value of these assets are more often materially misstated than other assets, and thus require greater audit effort. In addition to incorporating publicly available information into fees, auditors are also concerned with risks that are not presented in the financial statements. In a sense, auditors are corporate insiders who observe private information. They may also be better informed about the relative quality of public information. Because the auditor bares the risk for a failed audit and also has private information about the firm, the fees paid to the auditor may provide important signals to the market about firm transparency.

Even prior to the Enron scandal (breaking in 2001), and passage of the Sarbanes-Oxley Act of 2002, the SEC had become concerned about the nature of auditor fees and the transparency of financial information and markets. Interestingly, the SEC was somewhat less concerned with "audit fees" than with the "non-audit fees" paid to the auditor for consulting services. As Audits generated relatively low margins for the auditing firms, the SEC on highmargin non-audit fees which might compromise auditor independence. Thus, beginning February 5, 2001, the SEC required public disclosure of both audit and non-audit fees in firms' proxy statements in order to "give investors insight into the relationship between a company and its auditor" [SEC (2000)].

The availability of audit and non-audit fee data allows examine whether investors pay attention to the level of audit fees. Specifically we ask: (1) Do financial markets perceive over- 
investment (under-investment) in audit services as generating additional transparency (opacity)?

(2) Is transparency compromised when a firm pays abnormally high non-audit-related fees to the auditor?

Prior research on the role of auditors and on the role of auditor reputation on firm transparency has tended to focus in two areas. One strand of literature has focused on the certification role of auditors in the IPO and secondary offering markets. These papers observe that equity issuers face an adverse selection problem when issuing equity as suggested by Myers and Majluf (1984). Myers and Majluf (1984) note that a firm is more likely to issue equity when the market overvalues the firm's assets. Thus, investors are likely to suspect a lemon's problem for all equity issuances. Early research suggests that employing one of the "big name" auditors prior to an equity issuance mitigates this lemons problem so that both IPO underpricing and the share price declines associated with seasoned equity offerings are attenuated. Unfortunately, during the 1990's it became hard to test the effect of audit quality and audit fees on equity offerings because Big Five firms came to dominate the audit market for equity issuers. Evidence from seasoned equity issuances is also confounded by the agency problem of how management will actually deploy any money raised.

A second strand of literature concerning auditor reputation, auditor fees, and transparency has focuses on the informativeness of the financial statements themselves. In particular, discretionary accruals are seen as a source of significant audit risk and opacity. Numerous papers attempt to link audit and non-audit fees to the incidence and magnitude of discretionary accruals. However, as noted by Srinidhi and Gul (2007), the evidence here is mixed. A problem faced by this strand of research is that accruals are not uniformly uninformative. Managers can 
use accruals to either obscure financial conditions or to convey private information in a nonopportunistic way.

Our study addresses the relevant issues in a different manner. Rather than seeking evidence concerning how fees impact transparency indirectly, either by studying accruals or by studying event returns on equity issuances, we examine transparency though the lens of market microstructure. Specifically, we measure equilibrium (as opposed to event-driven) trading activities after the release of audit fee and financial statement data. As we discuss in detail in later sections, a large body of theoretical and empirical work suggests that bid-ask spreads are narrower for more transparent securities. Thus, we attempt to draw a connection between the magnitude of audit and non-audit fees and subsequent bid-ask spreads for the audited firms' traded equities.

Of course, large audit fees may simply reflect the fact that opaque firms require greater auditing effort. If this is so, we might reasonably expect that opaque firms will have both high audit fees and wide bid-ask spreads. Thus, fees and spreads would be positively correlated. On the other hand, if audit spending helps to improve transparency, fees and spreads should be negatively correlated. Danielsen, Van Ness and Warr (2007) conduct such a test, and conclude that for the set of S\&P 1500 firms, audit fees are positively correlated with spreads. This result is consistent with the idea that opacity is reflected in audit fees and spreads jointly. However, it would be premature to conclude that auditors do not lend transparency to security markets. An alternative interpretation of their results could be that the joint impact of inherent opacity on fees and spreads simply swamps the transparency benefits provided by robust audits.

With this in mind, it seems natural to ask the following question: assuming that higher cost audits can improve transparency, which firms are most likely to benefit from this 
improvement and will be willing to bear the higher cost? Drawing an insight from the seasoned equity issuance literature, it seems that firms who may need to tap the seasoned equity markets are likely to place a high value on auditor certification. This conjecture is supported by the migration of seasoned equity issuing firms to the "Big Five" accounting firms during the 1990's.

REITs provide a natural laboratory for considering how auditor services and fees impact transparency. REITs enjoy a special tax status as pass-though entities, but REIT tax law also requires that they distribute $90 \%$ of their earnings as dividends. As a result, REITs have difficulty retaining internally generated capital, and they are regular and systematic seasoned equity issuers as noted by Francis, Lys, and Vincent (2004). As repeat players in the seasoned equity market, audit quality and auditor reputation are likely to play an unusually important role in a REIT's capital acquisition plans. Thus, if the purchase of robust audit services can improve the liquidity for any firm, it seems especially likely to do so for REITs. REITs are also documented to be fairly immune to IPO hot and cold markets (Hartzell, Kallberg and Liu, 2005), consistent with their need to access capital markets on a recurring basis.

Previewing this paper's empirical results, our findings are at odds with those of Danielsen, Van Ness and Warr (2007). We find that firms which spend heavily on audit fees have tighter quoted spreads and tighter effective spreads, consistent with robust audits improving liquidity and lowering firms' cost of equity capital. However, we also find evidence (that is somewhat weaker) that the presence of abnormally large non-audit fees may reduce liquidity, consistent with the idea that auditor independence is seen as compromised.

Our paper is structured as follows: Section 2 reviews the literature on market microstructure measures, the literature on determinants of audit fees, and the literature on the role of auditor reputation in reducing opacity. Section 3 presents the empirical design for our 
study and the data. Section 4 reports results of our analysis, and Section 5 summarizes and concludes.

\section{Literature Review}

Our analysis draws on academic literature from both finance and accounting. Finance researchers have developed several "market microstructure" models to measure financial market transparency. These models use tick level trade data to infer information related trading costs. Accountants focus their research on transparency in the financial reporting process. This literature examines both the determinants of auditor fees and the importance of audit quality and auditor reputation on financial reporting transparency.

\subsection{Market Microstructure and Transparency in Financial Markets}

The role of asymmetric information has been examined from both a market microstructure perspective and a corporate finance perspective. As far back as Demsetz (1968) and Bagehot (1971), a connection is drawn between bid-ask spreads and the trading properties of underlying stocks. Amihud and Mendelson (1986) observe that investors require a premium for holding stocks with large bid-ask spreads because the spread induces illiquidity. An inference that can be drawn from Amihud and Mendelson's observation that bid-ask spreads increase expected returns is that managers who wish to increase their share price and decrease their cost of equity may do so by improving firm transparency, which will improve liquidity (reduce bidask spreads) in the security markets.

Kyle (1985) and Glosten and Milgrom (1985) model the presence of informed traders in non-transparent security markets and show how asymmetric information produces frictions in those markets. Of particular importance to this paper, Glosten and Milgrom show that the 
presence of traders with superior information produces a bid-ask spread even when the specialist is risk-neutral and makes zero expected profits. This spread increases as the degree of market transparency declines.

Several researchers examine the relation between firm characteristics and microstructure measures of asymmetric information such as the spread and effective spread. ${ }^{1}$ Brennan and Subrahmanyam (1995) find a correlation between the presence of analysts and microstructure measures of opacity. Similarly, Garfinkel and Nimalendran (2002) examine insider trading and observe that when corporate insiders trade their own stocks, spreads and effective spreads increase, while Flannery, Kwan, and Nimalendran (2004) analyze bank financial data and market microstructure data to conclude that "banking assets are not unusually opaque; they are simply boring."

We will proxy for security market transparency using bid-ask quoted spread and effective spread measures. The general idea that improved corporate transparency could be rewarded with smaller spreads is not particularly controversial. However, we acknowledge that our analysis does not address the myriad of facets of the asymmetric information problem. Asymmetric information takes many forms. Information asymmetries exist between the firm and investors and between the firm and its auditor as well. Spreads are more often thought of as resulting from information asymmetries between uninformed and informed traders, or between informed traders and uninformed market makers. Moreover, public information certainly interacts with trader's private information in complicated ways, as suggested in the models of Kim and Verrecchia (1994, 1997) and Lundholm (1991). For example, Lundholm argues, in contrast to our assumptions, that public signals may amplify the posterior disparity between uninformed and

\footnotetext{
${ }^{1}$ Subrahmanyam (2007), in a somewhat related paper, examines liquidity spillovers between the NYSE and REITs.
} 
informed traders so that more informative financial statements could actually increase spreads. We implicitly subsume these issues with the simplifying general assumptions that each of the types of information asymmetry are related, and greater transparency will reduce spreads more often than it will increase them. To the extent that this assumption over-simplifies the nature of asymmetric information, we gladly open the door to extension of this inquiry. With that said, we discuss our specific model choices in detail in the Data and Method section.

\subsection{Auditor Fees and their Determinants}

A very extensive literature has developed in accounting concerning the determinants of fees paid to auditors. These fees include those paid specifically for audit services, but also for non-audit fees which may be paid in conjunction with advice on acquisitions, mergers, and other transactions. Auditing firms also provide tax advice and other consulting activities. In a seminal paper, Simunic (1980) develops a pricing model for audit fees and concludes that size,

complexity (as measured by firm diversification, receivables and inventories, foreign operations), firm profitability, and the issuance of a qualified opinion are audit fee determinants. A short list of those who extend Simunic's work includes Low, Tan and Koh (1990), Chan, Ezzamel and Gwilliam (1993), Whisenant, Sankaraguruswamy and Raghunandan (2003), Brinn, Peel and Roberts (1994), Pong and Whittington (1994), O’Keefe, Simunic and Stein (1994) and McMeeking, Peasnell and Pope (2006).

Historically, auditing firms also performed significant consulting or non-audit services for client firms. Some of these non-audit activities were significantly more lucrative than the audit services, and they presented an apparent conflict of interest. Non-audit activities have been significantly curtailed by the Sarbanes-Oxley Act, but continued reporting of "other fees" in proxy statements provides evidence that more limited non-audit services continue. 
Frankel, Johnson and Nelson (2002) posit a "bribery" (or compromised-audit) argument. Abnormal accruals are frequently linked to managerial efforts to obscure the financial condition of the firm (reduce firm transparency). These authors find evidence of a link between large nonaudit fees and abnormal accruals. Ferguson, Seow and Young (2000), and Gore, Pope and Singh (2001) also find evidence of such links. However, Antle, Gordon, Narayanamoorthy and Zhou (2002) find no relation between accruals and fees. ${ }^{2}$

In this paper, we estimate several measures of abnormal audit fees, including the residual from a regression of audit fees on hypothesized determinants as described by Whisenant, Sankaraguruswamy and Raghunandan (2003). Abnormal audit fees can be thought of as the extra audit fees paid over what would be predicted by the financial and operating characteristics of the firm. Danielsen, Van Ness and Warr (2007) use the Whisenant, Sankaraguruswamy and Raghunandan (WSR) model, but they also note that the WSR model includes what may be an excessive number of explanatory variables. Accordingly, we also consider simplified measures of abnormal audit fees as proposed by Danielsen, Van Ness, and Warr.

\subsection{Auditor Reputation and Opacity}

It seems reasonable to suspect a positive correlation between audit fees and audit quality. The idea of heterogeneous quality among auditors was suggested and supported in Arnett and Danos (1979), Simunic (1980), and Shockley and Holt (1983). Noting that larger auditors charge higher fees than small auditors, Palmrose (1986) finds evidence that large auditors earn higher fees in part due to providing higher quality services. Lennox (1990) also examines the role of auditor fees and reputation in the provision of audit services, and Bar-Yosef and Sarath

\footnotetext{
${ }^{2}$ Bazerman, Loewenstein and Moore (2002) note that audit failures need not arise from fraud, but may arise for more mundane reasons. Auditors are vulnerable to unconscious bias when they have conducted an audit for several years. Thus, audit failure may result from a series of biased decisions rather than fraud.
} 
(2005) develop a model in which high fees also serve as a screening tool for auditors who wish to avoid attracting low quality clients.

Beatty (1989) and Firth and Liau-Tan (1998) argue that the market's perception of audit quality is particularly valuable to firms that are going public. New firms will pay a higher audit fee when the marginal cost to the firm of the "premium" audit is less than the marginal increase in IPO proceeds generated when investors incorporate the auditor's reputational capital into the security price. Beatty observes that "firms that pay a premium for their registration audit exhibit lower initial returns for their investors [abstract], " consistent with high-priced audits serving as a signal of informational transparency for IPO firms. Auditor reputation also appears to have played a role in the pricing of seasoned equity offerings by clients of Arthur Andersen LLP following the Enron scandal which broke in late 2001. Rauterkus and Song (2005) find that Andersen clients earned a 200 basis point more negative reaction to seasoned equity offerings compared to non-Andersen firms. ${ }^{3}$

The link between audit quality, auditor reputation, and equity offering prices (both IPO and seasoned), is of particular interest in this study. ${ }^{4}$ Because REITs are required to distribute 90\% of their earnings as dividends, REITs are regular and systematic seasoned equity issuers. Francis, Lys and Vincent (2004) observe that between 1992 and 1997 (six years), 127 REITs had 4.65 mean (5 median) seasoned equity issuances. As repeat players in the seasoned equity market, audit quality and auditor reputation are likely to play an unusually important role in REIT business planning. The role of the auditor in improving REITs' informational

\footnotetext{
${ }^{3}$ Datar, Feltham and Hughes (1991) also model the role of audit quality in mitigating asymmetric information problems between entrepreneurs seeking to conduct an IPO and the potential investors in that IPO.

${ }^{4}$ Hartzell, Sun and Titman (2006) examine the role of institutional investors on the investment policies of REITs. Institutional investors, like auditors, represent another form of monitoring.
} 
transparency, and thus the firm's cost of capital, may be more important than would be the case for firms whose internally generated cash flows can fund growth organically.

Instead of measuring the economic benefit of a higher quality audit as a higher IPO price, Danielsen, Van Ness and Warr (2007) consider the relationship between audit quality and equity market liquidity (as measured by bid-ask spreads.) This approach is consistent with Beatty's hypothesis, but it generalizes the value of high-quality audits beyond IPO firms. At its core, the Danielsen, Van Ness and Warr approach argues that because more transparent stocks trade with lower bid-ask spreads, buying a premium audit may improve transparency, increase liquidity, and result in a higher share price. However, the empirical findings by Danielsen et. al. are at odds with this hypothesis. Instead, they find that high-audit-fee firms have larger subsequent bid-ask spreads. They argue that this result seems more consistent with the idea that firms which are opaque to security markets are also opaque to the firm's auditors so that more audit effort is required for these firms. REITs represent a very different type of firm that those considered by Danielsen, Van Ness, and Warr who study auditor fees and bid-ask spreads for S\&P 1500 firms. Such large and mature firms, having no mandatory distribution rules, may be uniquely well suited to funding growth via internally generated capital. While it is an empirical question as to how often on average S\&P 1500 firms conduct SEOs, the frequency must be much less than for REITs, as reported by Francis, Lys and Vincent (2004). Accordingly, we might expect that the Danielsen, Van Ness and Warr S\&P 1500 sample is almost uniquely poorly suited for finding evidence that premium audit pricing is reflected in transparency metrics; REITs, in contrast, may be uniquely well suited for this purpose. 
Following a similar structure and method to Danielsen, Van Ness and Warr, we consider two sets of hypotheses. The first set examines audit fees; the second set examines non-audit fees. These hypotheses are as follows:

$\mathrm{H}_{1}$ : [Audit Fees] Firms that are more opaque are harder and more risky to audit. Auditors will charge higher fees to audit these firms. There will be a positive correlation between audit fees and subsequent security market measures of opacity.

$\mathrm{H}_{2}$ : [Audit Fees] Firms that wish to signal greater transparency will pay more for a higher quality audit and effectively purchase that auditor's reputational capital. There will be a negative correlation between audit fees and security market measures of opacity.

$\mathrm{H}_{3}$ : [Non - Audit Fees] Any fees paid by a firm to their auditor for non-audit services will serve to cloud the perceived objectivity of the auditor in its certification role. There will be a positive correlation between non-audit fees paid to the auditor and security market measures of opacity.

$\mathrm{H}_{4}$ : [Non - Audit Fees] Accounting firms gain valuable information about their clients' operations through ongoing working relationships with each firm, including through the provision of non-audit related services. To the extent such information/knowledge enhances the accuracy of audits, there will be a negative correlation between non-audit fees paid to the auditor and security market measures of opacity. 


\section{Data and Method}

In response to concerns over auditor independence, beginning February 4, 2001, the U.S. Securities and Exchange Commission (SEC) began requiring firms explicitly disclose the fees they paid to their auditors in their annual proxy statements. Specifically, the regulations called for the itemization of total fees into audit fees, information technology fees, and other non-audit fees, with the belief that such disclosures would enhance the transparency of each firm's financial statements. For this study, we obtain audit fee information from the AuditAnalytics database for the years 2001-2003. As the purpose of this investigation is to examine the potential linkages between audit fees and the financial market transparency of REITs, we augment the dataset with market microstructure characteristics derived from the NYSE Trades and Quotes Database (TAQ). Finally, to complete our sample dataset and ensure our empirical models were appropriately specified, we supplement the audit fee and microstructure data for each firm with additional accounting information and trading characteristic data obtained from CRSP and Compustat. A more complete description of the methodologies employed to construct our individual metrics is contained in the following sections.

\subsection{Abnormal Audit Fees}

While, to the best of our knowledge, the audit fee characteristics of REITs have yet to be critically examined, the accounting literature has developed an array of models testing the determinants of audit fees for industrial corporations. Given the potential difficulties in translating such models into the highly regulated environment in which REITs operate, we choose to employ three alternative approaches to assess the level of abnormal audit fees for an individual firm. 
First, following the approach of Whisenant, Sankaraguruswamy, and Raghunandan (2003), audit fees may be conceptualized as the compensation required by the auditor for the risks incurred in undertaking the audit. To the extent that the firm is informationally opaque, the auditor's risk associated with audit failure will increase. Thus, firms with more complex balance sheet and income statement characteristics should exhibit higher audit fees. To the extent the auditor extracts fees in excess of those required to compensate for the potential risk of loss associated with audit failure, those abnormal fees may either reflect greater auditor effort and scrutiny or economic rents earned by the auditor as compensation for lending the auditing firm's reputational capital to the REIT. In either case, these abnormal fees might be expected to convey assurance to investors. It follows that abnormal audit fees can be estimated as the residual from the following equation:

$$
\begin{aligned}
\ln [\text { Audit Fee] } & =\beta_{0}+\beta_{1} \ln \left[\text { Assets] }+\beta_{2} \ln \left[\text { Employees] }+\beta_{3} \text { Leverage }+\beta_{4}\right. \text { Liquidity }\right. \\
& +\beta_{5} \text { Invrec }+\beta_{6} \text { ROA }+\beta_{7} \text { Initial }+\beta_{8} \text { Foreign Ops }+\beta_{9} \text { Loss } \\
& +\beta_{10} \text { Sales_growth }+\beta_{11} \text { Qualified_opinion }+\beta_{12} \text { Employee_plans } \\
& +\beta_{13} \text { Book-to-market }+\beta_{14} \text { Disc Ops }+\beta_{15} \text { Restates }+\beta_{16-25} \text { Prop_Types } \\
& +\beta_{26} E \_R E I T+\beta_{27} \text { MTG_REIT }+\varepsilon
\end{aligned}
$$

where the right-hand-side variables are defined as follows: $:^{5}$

$\begin{array}{ll}\text { Assets } & =\text { Total Assets, } \\ \text { Employees } & =\text { Number of Employees, } \\ \text { Leverage } & =\text { Debt/Total Assets, } \\ \text { Liquidity } & =\text { Current Assets/Current Liabilities, } \\ \text { Invrec } & =[\text { Inventories + Accounts Receivable]/Total Assets, } \\ \text { ROA } & =\text { Net Income/Total Assets, }\end{array}$

\footnotetext{
${ }^{5}$ All the data items come from Compustat unless otherwise noted and are recorded for the fiscal year end (i.e., December) of the year in which the audit fees were charged.
} 
Initial $=1$ if auditor is in the first or second year of audit engagement, 0 otherwise,

Foreign Ops = 1 if the firm has foreign operations, 0 otherwise,

Loss $\quad=1$ if the firm reports negative net income in either of the previous two years, 0 otherwise,

Sales_growth = Growth rate in sales over the previous year,

Qualified_opinion= 1 if the firm received a qualified opinion in the current or previous year, 0 otherwise,

Employee_plans $=1$ if the company has pension plans, 0 otherwise,

Book-to-market $=$ Book to market ratio,

Disc Ops $\quad=1$ if the company had extraordinary items or discontinued operations, 0 otherwise,

Restates $\quad=1$ if the firm restated net income or assets for reasons other than an accounting rule change or adoption of new method, 0 otherwise,

Prop_Types $\quad=1$ if the REIT was operating within a given property type sector, 0 otherwise,

E_REIT $\quad=1$ if the firm was an equity REIT, 0 otherwise,

MTG_REIT = 1 if the firm was a mortgage REIT, 0 otherwise.

Our second metric of abnormal audit fees is designed to measure the importance of the audit client to the auditor. Following the approach of Frankel, Johnson, and Nelson (2002) we first group REITs by their auditor, then rank order the firms within each grouping based upon the total audit fees paid. A percentile ranking for each firm is then derived, with the highest revenue (i.e., most important) client for each auditor receiving a ranking of 100. Specifically, the Rank Audit Fee Percentile can be estimated as follows:

Rank Audit Fee $=\frac{[\text { Auditee's Audit Fee Rank Amongst Auditor's REIT Clients * 100] }}{\text { [\# of Auditor Specific REIT Clients] }}$ 
Where:

Auditee's Audit Fee Rank = 1 if the auditee paid the lowest fees of any REIT client for the specific auditor, 2 if the auditee paid the second lowest fees, ..., $\mathrm{n}$ if the auditee paid the highest fees amongst the auditor's n REIT clients.

Finally, our third measure of abnormal audit fees (the "DVW" method) follows the reduced form, industry-based abnormal audit fee model of Danielsen, Van Ness, and Warr (2007). DVW defines industry at the two digit SIC code level, and thus all the REITs within our sample may be viewed as operating with a single industry. However, we do observe wide variation in the property type segments in which our firms concentrate their investment activities. Thus, substituting in property-type segments for industry definitions, abnormal audit fees may also be estimated as the residuals of the following regression:

$$
\begin{aligned}
\ln [\text { Audit Fee] } & =\beta_{0}+\beta_{1} \ln \left[\text { Assets] }+\beta_{2} \ln [\text { Industry_Assets] }\right. \\
& +\beta_{3} \ln [\text { Industry_Audit_Fee] }+\varepsilon
\end{aligned}
$$

where:

Audit Fee = the auditee's audit fees paid to the auditor,

Assets $\quad=$ the total assets of the auditee,

Industry_Assets $=$ the average total asset level for all sample REITs operating within the same property type segment as the auditee, and

Industry_Audit_Fee $=$ the average audit fees paid by all sample REITs operating within the same property type segment as the auditee. ${ }^{6}$

\subsection{Microstructure Measures of Opacity}

In assessing the transparency of a firm's financial statements to the marketplace, we rely upon a pair of traditional market microstructure liquidity metrics; the quoted bid-ask spread and

\footnotetext{
${ }^{6}$ In robustness tests we have included fixed effects for the auditor in the WSR and DVW (equations (1) and (3)) abnormal fee models since different auditors may have different fee schedules. For instance, an auditor that was attempting to increase market share in REIT auditing might charge lower fees. Controlling for the auditor in a fixed effects framework addresses this possibility. We do not detect any substantive impact from this modification, and subsequent results use the WSR and DVW purging regressions described in the body of the text above.
} 
the effective bid-ask spread. Both of these metrics have long been recognized within the literature as being inversely related to the liquidity of the market for the underlying security, as well as being related to the informational opacity of the operating and financial characteristics of the underlying firm. ${ }^{7}$ Interestingly, however, considerable disagreement is found as to which measure more accurately represents the costs of transacting for the typical investor. Effective spread advocates correctly note that their measure is based upon actual observed transaction values as opposed to posted quotes. Thus, by definition, the metric should be closer to the transaction cost incurred by a typical trader. On the other hand, specialists and other market makers are not obligated to trade at any price other than their quoted bid and ask levels. In practice, they will likely only complete transactions inside their posted rates when they are confident they are not trading against a privately informed party and are not at an informational disadvantage. While the effective spread may provide a better estimate of the cost of reduced transparency, the quoted spread arguably provides a better measure of the magnitude of the transparency problems. Given the disagreement in the literature as to the appropriate metric, the current investigation will examine our key hypotheses using both quoted and effective spreads.

In calculating these alternative microstructure measures, we employ data from the NYSE Trades and Quotes (TAQ) database. Making use of techniques employed by previous researchers to minimize data errors, we impose a number of restrictive screens to ensure the accuracy and consistency of the spread data included in our analysis. Specifically, we omit trades and quotes that: 1) are flagged as out of time sequence, involve a correction, or involve an error; 2) have a bid price or ask price less than or equal to zero; 3) report a price or volume of

\footnotetext{
${ }^{7}$ For early discussions of the role of bid-ask spreads and the associated costs of contracting, see Demsetz (1968) and Bagehot (1971). For more recent applications of bid-ask spread and related liquidity analyses within the REIT sector, see Bhasin, Cole, and Kiely (1997), Capozza and Seguin (1999), Clayton and MacKinnon (2000), Danielsen and Harrison (2000), and Marcato and Ward (2007).
} 
zero for a completed trade; 4) report a negative bid-ask spread; 5) report a bid-ask spread in excess of $\$ 4$ per share; 6) possess time stamps corresponding to non-market hours of operation (i.e., "before-the-open" and "after-the-close" trades and quotes); and 7) exhibit transaction prices, bid-quotes, or ask-quotes exhibiting greater than a $10 \%$ deviation from the previously observed value along that same dimension.

For the purposes of this investigation, the quoted bid-ask spread, Spread $\mathrm{it}_{\mathrm{i}}$, is defined as the difference in the best ask price and the best bid price, for each firm i, at each point in time t:

$$
\text { Spread }_{i t}=\left(\text { AskPrice }_{i t}-\text { BidPrice }_{i t}\right)
$$

The midpoint of the spread is defined as the mean of the best ask and bid prices, for each firm $\mathrm{i}$, at each point in time $\mathrm{t}$ :

$$
\text { Midpoint }_{i t}=\frac{\left(\text { AskPrice }_{i t}+\text { BidPrice }_{i t}\right)}{2}
$$

Percentage Spread $_{\mathrm{it}}$, is the difference in the best ask and bid prices, divided by the midpoint of the spread (the ask price plus the bid price divided by two).

$$
\text { Percentage Spread }_{i t}=\frac{\text { Spread }_{i t}}{\text { Midpoint }_{i t}}
$$

To measure trading costs when transactions occur at prices inside the posted bid and ask quotes, we use the Effective Spread $_{\text {it, }}$ which is defined as:

$$
\text { Effective Spread }_{i t}=2 D_{i t}\left(\text { Trade }_{\text {Price }}{ }_{i t}-\text { Midpoint }_{i t}\right)
$$


where Trade Price ${ }_{i t}$ is the transaction price for security $i$ at time $t$, Midpoint $_{i t}$ is the midpoint of the most recently posted bid and ask quotes for security $i$ at time $t$, and $D_{i t}$ is a binary variable which equals +1 for customer buy orders and -1 for customer sell orders. ${ }^{8}$

\subsection{Additional Sample Construction Considerations}

While approximately 180 REITs are actively traded on an organized U.S. exchange or NASDAQ during each year of our analysis, we are able to obtain the relevant audit fee information for only approximately $60 \%$ of these organizations. In addition, to ensure direct comparability of our variable specifications across firms, only REITs with December fiscal year ends were retained within the sample. ${ }^{9}$ After merging data from AuditAnalytics, TAQ, CRSP, and Compustat, and after eliminating observations with missing, inapplicable, or clearly erroneous data, we are left with 300 firm-year observations in our final dataset. ${ }^{10}$

In the empirical model specifications which follow, we test the relationship between the financial market opacity of the firm during August of a given year and the firm's financial condition and audit characteristics at the end of the previous year. Year-end financial records and proxy statements for firms with December fiscal year-ends will generally be made publicly available during the spring of the subsequent year. By August, market participants should have had time to digest all relevant information and deficiencies contained within these statements, and markets will have incorporated any relevant factors into observed market prices and spreads. To the extent that these information releases dissipate in value prior to August, such a temporal aggregation deficiency should bias our results against finding any relationship between abnormal audit fees and microstructure trading characteristics. Given the temporal lag required to relate

\footnotetext{
${ }^{8}$ See Lee and Ready (1991) for further discussion of the trade direction indicator.

${ }^{9}$ In reality, this constraint is of little impact on the final results as the vast majority of REITs employ December fiscal year ends - presumably to ease their compliance with IRS related tax exemption mandates.

${ }^{10}$ More specifically, we have 92, 106, and 102 observations for fiscal years 2001, 2002, and 2003 respectively.
} 
the financial (including audit fee metrics) and trading characteristics of REITs, we map our accounting information from 2001-2003 onto microstructure data from August 2002-2004.

Having established the general framework of the data to analyzed, we now turn explicitly to our empirical analysis.

\section{Analysis}

\subsection{Auditor Fee Characteristics}

As this study represents the first empirical investigation utilizing audit and related fees for REITs, we begin our analysis by documenting the typical audit costs incurred by these organizations. Panel A of Table 1 outlines the auditors employed by publicly traded REITs, and summarizes the range of audit fees charged by each of these firms. Examining the data, it is clear that most publicly traded REITs rely on Big Four accounting firms to conduct their audits, with Ernst \& Young having the dominant position within this market sector. Prior to its demise, Arthur Andersen was also an active participant within this industry. This heavy reliance on high profile auditors is consistent with the certification effect outlined above. As extensive dividend payout requirements force REITs to continually access public capital markets to finance their continued growth, the ability to credibly signal the firm's financial position (i.e., financial transparency) is both uniquely and critically important to firms within this industry.

Examining the data more closely reveals tremendous variation across firms in the cost of obtaining audit services. Audit and Related Fees range from a low of $\$ 42,500$ paid by Boykin Lodging Co. to Arthur Andersen for fiscal year 2001, to a high of $\$ 10.2$ million paid by Apartment Investment \& Management Co. to Ernst \& Young for fiscal year 2002. Panel B provides a similar breakout for the non-audit fees paid by REITs to their primary auditor, and again reveals substantial variation across firms. While every auditor surveyed had at least one 
client from which they received no non-audit related income, all five high profile accounting firms each had at least one firm whom they charged over $\$ 1,000,000$ per year for non-audit related services. Surprisingly, four of the big five (counting Arthur Andersen for 2001) had at least one client paying over \$2,000,000 per year, with Ernst \& Young receiving the highest single year pay-off of \$10.7 million from Apartment Investment \& Management Co. for fiscal year 2001. ${ }^{11}$

Two additional facets of audit and non-audit fees, both fundamentally related to regulatory changes, should also be noted. First, unreported findings show a dramatic decline in the level of non-audit related fees in the post Sarbanes-Oxley era. Specifically the average level of non-audit fees for REITs declined from over $\$ 540,000$ per firm in 2001 , to less than $\$ 100,000$ per firm in 2002, and even further to less than $\$ 50,000$ per firm in 2003 . Conversely, direct audit fees increased substantially over this same interval; average REIT audit fees in 2001 were $\$ 435,000$; in 2002 they were $\$ 777,000$; and by 2003 they had risen to $\$ 873,000$. In sum, direct audit fees doubled during our period of analysis, while revenues from non-audit related services and activities declined by approximately ninety percent. Taken together, these results indicate non-audit related services represented approximately $55 \%$ of REIT auditor income in 2001, but these fees had drop to less than $6 \%$ of income by 2003 .

Turning to Table 2, we compare both audit and non-audit related fees across differing property types. Once again, considerable variation is observed both across property type classifications and across firms within individual segments. While we note that Lodging, Residential, and Diversified REITs appear to be characterized by relatively high audit fees, given

\footnotetext{
${ }^{11}$ While our data do not extend to the pre-2001 period, Ernest \& Young actually received over $\$ 15$ million in nonaudit related income from Apartment Investment \& Management Co. for fiscal year 2000. By 2004, these fees had been reduced even further, to less than $\$ 2$ million annually.
} 
the complex array of factors which may influence the determination of audit fees we choose to defer definitive judgment about the nature of specific audit fee relationships until our multivariate analysis. That said, it is somewhat informative to compare the ratio of audit to nonaudit fees across property type segments. This metric ranges from highs of 9.52 for Diversified REITs and 6.77 for Mortgage REITS, to lows of 2.18, 2.80, and 3.15 for Residential, Retail, and Self-Storage REITS respectively. Interestingly, firm's operating in multiple market segments or investing in financial assets are generally found in the literature to be more informationally opaque. To the extent more informationally opaque firms are characterized by higher audit premiums, the relatively high ratios for Diversified and Mortgage REITs would seem to be consistent with the previous literature. Similarly, firms with relatively stable cash flows have been shown to be informationally transparent. To the extent Residential (i.e., apartment), Retail, and Self-Storage REITs are characterized by predictable lease terms and cash flows, these ratio findings may again be consistent with the previous literature.

Having documented the general nature of audit fees across both audit firms and property types, we next examine our sample firm characteristics in more detail to provide the context for our multivariate results which follow.

\subsection{Firm Level Descriptive Statistics and Univariate Comparisons}

Table 3 provides descriptive statistics for the sample firms and market microstructure characteristics employed throughout the remainder of our analysis. All numbers reflect the composite findings across the 300 firm year observations included in our final dataset. The typical firm in our sample holds roughly $\$ 3$ billion in assets and employs about 1,700 people. Over $91 \%$ of our observations come from equity REITs. Consistent with previous findings for this industry, REITs are (on average) more highly levered than their industrial firm counterparts 
- the average total debt ratio for our sample is nearly $65 \%$. They also frequently report losses due to the large depreciation allowances they enjoy - over $10 \%$ of our firm year observations reported net losses despite a relatively robust average revenue growth rate in excess of $13 \%$. Extraordinary items and/or discontinued operations were reported by nearly $30 \%$ of the firms within our sample, while a surprisingly large $44 \%$ have received a qualified opinion during the current or previous year. ${ }^{12}$ Similarly, fully one half of the sample firms within our dataset have materially restated earnings or assets for reasons other than methodological or accounting rule changes. While beyond the scope of the current investigation, we find this proclivity to continually restate earnings worthy of further research.

Turning to our market microstructure characteristics we find the sample to be dominated by NYSE firms, with only 10 of the 300 firm year observations coming from NASDAQ traded REITs. Quoted spreads average $0.37 \%$ of the market price of the underlying security. This number is marginally lower, but exhibits more volatility, than the $0.41 \%$ reported by Danielsen, Van Ness, and Warr (2007) for industrial firms. Effective spreads average $0.24 \%$, with this lower value reflecting trades occurring inside the market maker's posted quotes. Once again, this number is marginally lower than the $0.36 \%$ reported by DVW for industrial firms, potentially suggesting real estate investment trusts are more informationally transparent than their industrial firm counterparts. ${ }^{13}$

Continuing, Table 4 outlines the correlations between our key variables of interest. Audit fee and abnormal audit fee metrics appear to be positively correlated with each other and (generally) negatively correlated with bid-ask spreads. Likewise, the corresponding relationships

\footnotetext{
${ }^{12}$ Given our multi-year period of analysis, this $44 \%$ likely overstates the true frequency of receiving qualified opinions. For example, if firm A received a qualified opinion during 2001, their records would be flagged for both firm years 2001 and 2002.

${ }^{13}$ For further discussion of the informational transparency of real estate investment trusts and their relative valuation difficulty, see Han (2006).
} 
for other fees (and abnormal other fees) are positive and statistically significant. However, only one of the eight correlations between our four other fee and two bid-ask spread variables is significantly different from zero at the ten percent significance level. As expected, there is a strong negative association between both firm size metrics (total assets and the market value of equity) and both spread measures. Consistent with the previous literature, larger firms tend to be more informationally transparent and liquid.

\subsection{Multivariate Tests of Audit and Non-Audit Fees as a Determinants of Financial Market Opacity}

In Tables 5 and 6 we examine the impact of audit fees and non-audit fees on both the quoted and effective bid-ask spreads of real estate investment trusts. To measure the true marginal impact of these audit variables on financial transparency, and hence spreads, we must properly specify our models to accurately control for additional factors that may influence observed spreads. Previous work has shown the number of trades, trade size, and intraday quote volatility to be important control variables in the determinants of the spread (see Chung, Van Ness and Van Ness, 2001). Numerous papers also document significant differences in spreads across trading systems (see for example Huang and Stoll, 1996), while increasing firm size has consistently been found to be associated with increased liquidity for a security and hence lower spreads.

One important source of asymmetric information for REITs is likely to be uncertainty surrounding Net Asset Value. Reliable NAV measures for these REITs would be difficult or impossible to obtain. However, it seems important to control for asset valuation uncertainty in some manner. Given that some property types may be more difficult to value than others, we include property-type dummies (fixed effects) as control variables in the regressions which 
follow. We also include the number of analysts following the stock to further control for the amount of information available to market participants. Finally, given the unique financing situation faced by REITs, in which they are forced to continually access public capital markets to raise funds for continued growth, we posit that real estate investment trusts with increased growth opportunities should exhibit an increased incentive to demand financial transparency.

Based upon these previous findings regarding the determinants of bid-ask spreads, the regression models we estimate take the following general form:

$$
\begin{aligned}
{[\text { Bid-Ask Spread }]=} & b_{0}+b_{1}[1 / \text { Number of Trades }]+b_{2}[1 / \text { Trade Size }]+b_{3} \text { Price } \\
& +b_{4}[1 / \text { Standard Deviation of Quote Midpoint }] \\
& +b_{5} \text { Number_of_Analysts }+b_{6} \text { Abnormal_Audit_Fees } \\
& +b_{7} \text { Exchange }+b_{8} \ln [M V E]+b_{9} \text { Market-to-Book } \\
& +b_{10-19} \text { Prop_Types }+\varepsilon
\end{aligned}
$$

where, Bid-Ask Spread is either the quoted spread or effective spread as a percentage of the price, Number of Trades is the average daily number of trades, Trade Size is the average daily trade size, and Standard Deviation of Quote Midpoint is the average daily standard deviation of the quote midpoint during the month studied. Number of Analysts is the number of analysts reported for the month by $\mathrm{I} / \mathrm{B} / \mathrm{E} / \mathrm{S}$ - FirstCall. Exchange is a dummy variable that takes the value of one if the stock is listed on NASDAQ, zero otherwise; $\ln (\mathrm{MVE})$ is the natural log of the firm's market value of equity; and book-to-market is the ratio of the firm's book value of total assets to the market value of their total assets. A series of dummy variables denoting the property type are also included (although the coefficients on these variables are not reported).

A larger number of trades would be expected to decrease the cost of transacting for the market-maker, as fixed costs can be spread over a larger number of transactions. Similarly, as NYSE firms are generally larger and more informationally transparent than their NASDAQ counterparts, we expect NASDAQ REITs to be characterized by higher spreads. In addition, as 
book-to-market ratios are widely viewed as reasonable (inverse) proxies for a firm's growth opportunities, we also expect this ratio to be positively associated with our spread/opacity metrics. Thus, we expect $b_{1}, b_{7}$, and $b_{9}$ to exhibit positive signs.

Larger average trade sizes expose the market-maker to increased risk, both in terms of having to hold larger non-diversifiable inventories of the security in order to maintain immediacy in the marketplace as well as exposing them to larger expected losses in the event they trade with privately informed parties. Similarly, more volatile securities also expose the market-maker to increased risk along these same dimensions. To the extent that analysts produce valuable information about the firms they cover, analyst scrutiny is likely to reduce information asymmetries. Also, since firms which do not court analysts tend to have fewer analysts following the firm, the presence of a large number of analysts suggests that management is relatively comfortable disclosing information to analysts and the public. Both management's willingness to talk and analysts desire to distribute their findings suggest that more analysts should improve the information environment. Finally, larger and more highly valued firms should receive more analyst coverage, thus reducing their levels of private information and associated spreads. We thus expect $b_{2}, b_{3}, b_{4}, b_{5}$, and $b_{8}$ to have negative signs. ${ }^{14}$

Finally, given the alternative explanations outlined above regarding the expected relationship between audit fees and firm transparency, we leave the expected sign on $b_{6}$ as an open empirical question.

Table 5 presents the results of the estimation of equation 8 . The first three columns all use the quoted bid-ask spread as the dependent variable, while varying the metric employed to

\footnotetext{
${ }^{14}$ In untabulated tests we have used [1/ dollar volume] as an alternative measure of trading activity. Average dollar volume is the product of average trade size, the average number of trades, and the price. When using the dollar volume variable we dropped the other three variables. The results for the variables of interest are not substantively changed by this substitution.
} 
measure abnormal audit fees. In column 1, the abnormal audit fee metric is the fully specified Whisenant, Sankaraguruswamy, and Raghunandan (2003) residual; in column 2 the abnormal audit fee is the rank audit fee metric of Frankel, Johnson, and Nelson (2002); and in column 3 the abnormal audit fee is the residual from the reduced form industry/property type specific model in the spirit of Danielsen, Van Ness, and Warr (2007).

Examining the results for quoted spreads, we find that the coefficients on all eight nonaudit related determinants of financial market opacity are consistent with their hypothesized signs. Seven of these eight relationships are statistically significant at traditional levels, with the market-to-book ratio being the only control variable that that is not statistical significant. Turning to our key variables of interest, the abnormal audit fees, we find some evidence suggesting that over-investing in an audit enhances the transparency of a firm's financial statements and, thus, reduces observed bid-ask spreads. Specifically, in column 1, the WSR residuals are marginally significant (negative) predictors of observed spreads, while the rank audit fee numbers presented in column 2 appear to be relatively important (again negative) determinants of firm opacity. The DVW metric in column 3 is statistically insignificant, but directionally consistent with the findings in columns 1 and 2 . Taken together, these three alternative models provide evidence that is consistent with the hypothesis that that REITs may over-invest in audit services when they wish to enhance the credibility of their reported financial statements.

The final three columns of Table 5 replicate the previous analysis using effective spreads rather than quoted spreads. Once again, all control variables have statistically significant coefficient estimates that are consistent with their hypothesized signs. Examining our audit fee measures, the effective spread results are considerably stronger than those previously reported 
for quoted spreads. This time, and in clear contrast to the findings of Danielsen, Van Ness, and Warr for large industrial firms, all three abnormal audit fee metrics are significantly negative. As previously discussed, these results suggest that auditors of REITs play a key certification role with respect to the transparency of a firm's financial statements. This role is critically important to real estate investment trusts that have a frequent need to return to the capital market.

We next examine whether non-audit fees influence REIT transparency. Specifically, do non-audit based relationships create potential conflicts of interest for audit firms in evaluating an auditee's financial records, or do they create access to additional company specific private information which may be used to enhance the accuracy of the audit and improve the financial transparency of the firm? ${ }^{15}$ Table 6 replicates the analyses in Table 5 using abnormal non-audit fees and the rank of non-audit fees paid to each auditor. Once again, all firm specific and market microstructure control variables are consistent with their expected signs. Six of these eight controls are statistically significant across all model specifications, while our Trade Size metric exhibits modestly greater explanatory power over effective spreads than quoted spreads. The market-to-book ratio remains insignificant at conventional levels across each of our alternative specifications.

Focusing in on our key non-audit fee relationships, all three of the non-audit fee variables are significant, positive predictors of both quoted and effective spreads. These results are consistent with the hypothesis that the market views non-audit based relationships as creating potential conflicts of interest for the auditor, thereby diminishing auditors' ability to credibly signal the accuracy of financial statement for their auditees.

\footnotetext{
${ }^{15}$ An alternative explanation for the correlation between abnormal audit fees and market based measures of opacity is that auditors may be bribed with high fees to provided unqualified audit opinions.
} 
For robustness, we repeated the tests in Tables 6 and 7 using raw quoted spreads and raw effective spreads, rather than spreads scaled by price. For raw quoted spreads, the t-statistics of coefficients on the abnormal audit fee measures ranged from -1.93 to -3.22 . These results are slightly stronger than the results reported in Table 5. For raw effective spreads, the t-statistics of coefficients on abnormal audit fee measures ranged from -2.38 to -3.58 .

Using raw spreads as left-hand side variables in "other fee" regressions similar to those conducted in Table 6 yielded results that were mildly weaker, in the sense that the abnormal other fee t-statistics were uniformly lower than those tabulated in Table 6. However, four of the six abnormal other fee t-statistics were positive and significant at the one percent level and one was significant at the five percent level. The t-statistic on the WSR-calculated abnormal other fee was 1.53, which does not attain standard levels of statistical significance. Taken as a whole, we conclude that the use of raw spreads in the regressions reinforces the initial findings presented in the tables. ${ }^{16}$

As previously noted, the potential effects of abnormal audit and non-audit fees are interrelated (as noted in hypotheses $\mathrm{H} 3$ and $\mathrm{H} 4$ ). On one hand, high non-audit fees could serve to undermine the ability of the audit to credibly signal quality. Conversely, an "informational economies of scope" argument can be made that information gathered during non-audit activities may serve to make audits more valuable. Given potential relationships between the two types of fees, it makes sense to reexamine Table 5 and Table 6 regressions when both types of abnormal fees are included as regressors simultaneously. The results of these tests are reported in Table 7.

\footnotetext{
${ }^{16} \mathrm{We}$ also have investigated whether the relation between spreads and audit fees changes after passage of the Sarbanes Oxley Act of 2002 (Sarbox). To test for this possibility, we created a dummy to flag post-Sarbox observations and interacted the dummy with the fee measures. Although mean spreads declined, we do not find a change in the relation between spreads and audit fees post-Sarbox.
} 
The first three column of Table 7 report results for regressions on the percentage quoted spreads. The last three columns report results for percentage effective spreads. The abnormal audit fees and the abnormal other fees for each regression are calculated in an internally consistent manner. For example, in the first column, both abnormal fee metrics are the residuals captured from WSR purging regressions (as described in equation 1.)

The first noteworthy attribute in the Table 7 regression is that the significance level declines on all the coefficients for the abnormal audit fees and the abnormal other fees, relative to their counterparts in Tables 5 and 6 . This is most noticeable when examining the coefficients on Abnormal Audit Fees in the quoted-spread regression. While two of the three quoted-spread specifications were statistically significant in Table 5, none of the specifications is statistically significant in Table 7. However, for regressions which consider effective spreads, two of three abnormal audit fee coefficients remain statistically significant. The DVW abnormal audit fee coefficient falls slightly short of statistical significance.

For the abnormal other fee coefficients, while their statistical significance is universally lower than the corresponding Table 6 results, each specification remains statistically significant.

\subsection{Tests of Changes in Fees as a Determinants of Changes in Spreads}

Since we have hypothesized that over-investing in an audit enhances the transparency of a firm's financial statements and, thus, reduces observed bid-ask spreads, we next consider whether year-to-year changes in abnormal fees result in changes in spreads. Table 8 presents results from tests conducted using the following general form:

$$
\begin{aligned}
\Delta[\text { Bid-Ask Spread }]= & b_{0}+b_{1} \Delta[1 / \text { Number of Trades }]+b_{2} \Delta[1 / \text { Trade Size }] \\
& +b_{3} \Delta \text { Price }+b_{4} \Delta[1 / \text { Standard Deviation of Quote Midpoint }]
\end{aligned}
$$




$$
\begin{aligned}
& +b_{5} \Delta \text { Number_of_Analysts }+b_{6} \text { Abnormal_Audit_Fees } \\
& +b_{7} \Delta \text { Exchange }+b_{8} \Delta \ln [M V E]+b_{9} \Delta \text { Market-to-Book }+\varepsilon
\end{aligned}
$$

The regressand, $\Delta[$ Bid-Ask Spread], is the change in the spread from one year to the next. This variable is regressed on the change in each of the right-hand-side variables from equation 8 . We would expect that each control variable will each have the same coefficient sign as the corresponding level-variable coefficient in equation 8 . The first three specifications in Table 8 address changes in audit fees, and the final three specifications address changes in other fees.

For conciseness, Table 8 reports results for changes in effective spreads only, but we will also discuss the results for quoted spreads. Two comments are merited on these regressions. First, the $\Delta$ Exchange variable has been dropped because none of the firms changed exchanges during the sample period. Second, the adjusted $\mathrm{R}^{2}$ for each regression is substantially lower than the adjusted $\mathrm{R}^{2}$ of regressions on fee levels (as opposed to changes) in prior tables. This result suggests that the change data is much noisier than the data for levels. Nevertheless, we observe that all but two of the control variables carry the anticipated sign, and most carry the correct sign at statistically significant levels. $\Delta$ Trade Size and $\Delta$ Number of Analysts and $\Delta$ Market-to-Book Ratio cannot be statistically distinguished from zero.

Most importantly for our purposes, in the first three specifications, positive changes in abnormal audit fees result in declining spreads, as predicted. Also, each of the three values is statistically significant. This result supports the hypothesis that over-investing in an audit enhances the transparency of a firm's financial statements and reduces spreads. In the final three specifications, changes in each the Other Fee metrics are positively related to changes in effective spreads. The results are statistically significant and consistent with the prior results from Tables 5, 6 and 7. 
While the results shown in Table 8 are uniformly supportive of the hypothesis that overinvestment in audit fees lowers REIT effective bid-ask spreads, the untabulated results for regressions on quoted spreads are less compelling. For quoted spreads, none of the " $\Delta$ Abnormal Audit Fee" coefficients are statistically significant in stand-alone regressions, although they uniformly possess the correct mathematical sign. Perhaps this is unsurprising given the higher statistical significance levels for all effective spread specifications in Tables 5, 6 and 7, relative to their quoted-spread specifications.

The quoted-spread counterparts to the " $\Delta$ Other Fee" regressions in Table 8 produce coefficient estimates that are positive and statistically significant in two of the three specifications. The " $\Delta$ Rank Other Fee" variable produces the statistically insignificant coefficient ( $\mathrm{p}$ value $=.19$ ). In robustness tests, placing the audit and other fee variables on the right-hand-side of the same regression, as in Table 7, consistently lowers the statistical significance of both the $\Delta$ Audit Fee variable and the $\Delta$ Other Fee variable. However, all of the specifications possess the correct signs on the coefficients of interest, and most are statistically significant at high levels. The " $\Delta$ Other Fee" coefficients are always statistically significant when using " $\Delta$ effective spread" as the left-hand-side variable.

\subsection{Tests Comparing REITs to the Universe of Firms}

As a final test, we attempt to determine whether the preceding results actually capture a unique feature of REITs as a pass-through entity by performing a test on the universe of firms (not just REITs) and including an interaction of our abnormal fee metrics and a REIT dummy. If spreads are more responsive to over-investment in audit fees for REITs than for other firms, we expect that this interaction variable will carry a negative coefficient. 
In order to conduct these cross-sectional tests on the universe of firms, we collect additional data for all non-audit firms, consistent with the methods and techniques previously described in Section 3. We then conduct cross-sectional regressions which mirror the tests in Tables 5, 6 and 7. Specifically, based upon prior tests, our regression models take the following general form:

$$
\begin{aligned}
& \text { [Bid-Ask Spread] }=b_{0}+b_{1}[1 / \text { Number of Trades }]+b_{2}[1 / \text { Trade Size }]+b_{3} \text { Price } \\
& +b_{4} \text { [1/Standard Deviation of Quote Midpoint] }+b_{5} \text { [Number of Analysts) } \\
& +b_{6}\left[\text { Abnormal Fees] }+b_{7} \text { [Abnormal Fee } \times R E I T\right. \text { Indicator] } \\
& +b_{8} R E I T \_I n d i c a t o r+b_{9} \text { Exchange }+b_{10} \ln [M V E]+b_{11} \text { Market-to-Book } \\
& +\varepsilon
\end{aligned}
$$

The only new variable in this test is the REIT Indicator variable; a dummy variable taking the value of one if the firm is a REIT, zero otherwise. The coefficients of interest in this regression are those on Abnormal Fees, REIT Indicator, and (most importantly) the interaction of Abnormal Fee and REIT Indicator. Table 9 presents the results. The first three specifications in Table 9 address changes in audit fees, and the final three specifications address changes in other fees. Again, for conciseness, Table 9 reports results for changes in effective spreads only. Results using quoted spreads are substantively the same.

In all the regression specifications, the coefficient on REIT Indicator is positive and indicates that REITs, on average, have larger spreads than other firms after controlling for other determinants. Turning to the variables of interest, the first three columns in the table utilize the three alternative metrics for abnormal audit fees. While each of the three abnormal audit fee metric coefficients carries a negative point estimate, the two more refined metrics, the WSR and DVW metrics, are not statistically significant. In contrast, the RANK metric, which is a raw ranking of audit fee values for each auditor's clients, is highly significant. Recall that the RANK metric is designed to measure the importance of the audit client to the auditor. The RANK 
variable takes on values between zero and one, with the auditor's largest fee generator given a value of one. As a result, PricewaterhouseCoopers' median client will have a RANK value of .5, but a small local auditor's largest firm will have a RANK value of one. Thus heterogeneity of auditors in the universe of firms makes interpretation of the coefficient on RANK difficult. Given that the more refined abnormal fee metrics cannot be distinguished from zero, we are inclined to interpret these results as being inconsistent with the proposition that overinvestment in audit fees leads to lower spreads in the universe of firms.

Turning to the findings for abnormal other fees, the final three columns of Table 9 present a very different result. Here we see positive coefficients which have extremely high statistical significance, a result found in all specifications. We interpret this result as unambiguous evidence that firms with unusually high non-audit fees are unusually opaque to the market as evidenced by higher bid-ask spreads.

Finally, let us turn to the coefficients of greatest interest to this study, the coefficient on the interaction term between REIT Indicator and Abnormal Audit Fees. In the first three columns of the table, the interaction term carries a negative coefficient for each specification. For the more refined abnormal fee metrics, WSR and DVW, the coefficients are statistically significant. The RANK fee coefficient is not statistically significant (t statistic $=-1.41$ which equates to a p-value of 0.158 ). We interpret the results from the WSR and DVW specifications as supporting the proposition that while firms in general do not have lower spreads when they over-invest in audit fees, REITs are different. The negative coefficient on the interaction terms suggest that REITs, in contrast to other firms, do have lower spreads when they over-invest in audits. These results are not supported by the regression using the RANK fee variable, but this 
variable is less refined, and it is particularly difficult to interpret when applied to the universe of firms.

For completeness, consider the interaction variable in the last three specifications on Table 9. These are the specifications using abnormal-other-fee variables. Here, the interaction terms are not different from zero. Our interpretation of the results for abnormal other fees in Table 9 is that when firms pay unusually high non-audit fees, they are unusually opaque to the financial markets. This is true in the universe of firms, and REITs conform to this general rule. The results shown in prior REIT-only tests for abnormal other fees appear to reflect a relationship that is not unique to REITs. This is in contrast to the unique status of REITs where abnormal audit fees are concerned.

\section{Conclusion}

This study addresses the role that auditors, and the compensation structure of auditing firms, play in the transparency of financial markets. In a sense, auditors are the market's "designated insiders" whose actions are intended to lend clarity to published financial data. However, auditors are neither selected by, nor paid by, investors. They are employed by the audited firm. Thus, auditors must balance the reputational value of their activities against the potential conflicts of interest which are inherent in the audit relationship.

Financial markets are generally understood to reward corporate transparency with improved financial market liquidity; with lower bid-ask spreads in particular. Thus, firms have an incentive to strive for some level of transparency by engaging a credible and thorough auditor. Of particular importance to this study, firms that are likely to be equity issuers are likely to see 
value in maintaining transparency and in signaling such transparency. An obvious mechanism by which they might signal transparency is by "over-investing" in the audit services relative to other firms. For this reason, we focus our analysis on REITs, which for regulatory reasons are frequent participants in SEO markets.

Operationally, we ask the following questions: Do REITs that pay abnormally high audit fees signal greater transparency that is subsequently reflected in financial market measures of transparency? If so, bid-ask spreads should be smaller when audit fees are high. Alternatively, might abnormally high audit fees indicate that auditors have found the firm to be unusually opaque so that more auditing effort is required? In this case bid-ask spreads should be larger when audit fees are high. Prior research has concluded that the latter hypothesis is valid, but no empirical support exists for the former. In selecting REITs as the laboratory for our experiment, we have chosen a set of firms where the ability to detect the benefits of over-investment in the audit process is likely to be unusually strong. Illiquidity in the secondary markets can have a direct impact on these firms' abilities to raise capital in the SEO market.

Empirically, we find consistent evidence that, at least for REITs, "over-investment" in the audit function is reassuring to the financial markets. Firms with unusually high audit costs are rewarded with lower bid-ask spreads and improved liquidity. Moreover, REITs with increasing abnormal audit spending appear to have improved subsequent liquidity, as measured by bid-ask spreads. In contrast, we do not find this relationship for the non-REIT universe of firms. Nevertheless, it seems likely that non-REIT firms that have an impending need to access equity markets may over-invest in audit services in order to improve transparency.

This paper also addresses the signal sent when non-audit fees charged to firms by their auditors are abnormally high. Auditing firms have historically earned fees from both auditing 
services and non-audit-related consulting activities. Although the Sarbanes-Oxley Act of 2002 reduced the relative magnitude of non-audit to audit fees, accounting firms continue to earn nonaudit related fees.

Even prior to the Sarbanes-Oxley Act, the SEC had begun to require disclosure of nonaudit fees in proxy statements, fueled by the SEC's concern that fees paid by a firm to their auditor for non-audit services might cloud the auditor's objectivity. Accounting firms countered that they gain valuable information about their clients' operations through the provision of nonaudit services.

The SEC's argument suggests that abnormal non-audit-related fees will reduce transparency and increase bid-ask spreads for stocks. The counter argument suggests that these fees are associated with improved transparency which reduces spreads. We observe evidence that high non-audit fees result in reduced transparency and higher bid-ask spreads for REITs. However, our tests also suggest that this relationship that is not unique to REITs, and exists in the universe of firms.

In summary, we find that capital markets reward REITs that "over-invest" in audit services with better liquidity as measured by bid-ask spreads. We infer that financial markets are reassured by robust spending on audit services. However, REITs with abnormally high nonaudit expenditures have poorer liquidity, although this relationship appears to be generalizable to the universe of firms. We infer that high non-audit fees are perceived by the market as potentially compromising the auditor's independence. 


\section{REFERENCES}

Amihud, Y. and H. Mendelson (1986), "Asset pricing and the bid-ask spread", Journal of Financial Economics, Vol. 15, pp. 223-49.

Antle, R., E. Gordon, G. Narayanamoorthy and L. Zhou (2002), "The Joint Determination of Audit Fees, Non-Audit Fees and Abnormal Accruals", Working paper (Yale University).

Arnett, H. E. and P. Danos (1979), CPA Firm Viability, Ann Arbor, University of Michigan.

Bagehot, W. (1971), “The Only Game in Town”, Financial Analysts Journal, Vol. 27, pp. 12-14.

Bar-Yosef, S. and B. Sarath (2005), "Auditor Size, Market Segmentation and Litigation Patterns: A Theoretical Analysis", Review of Accounting Studies, Vol. 10, pp. 59-92.

Bazerman, M., G. Loewenstein and D. Moore (2002), "Why Good Accountants do Bad Audits", Harvard Business Review, November, pp. 97-102.

Beatty, R. (1989), “Auditor Reputation and the Pricing of Initial Public Offerings", The Accounting Review, Vol. 64, pp. 693-709.

Bhasin, V., R. A. Cole, and J. K. Kiely (1997), "Changes in REIT Liquidity 1990-1994:

Evidence from Intraday Transactions," Real Estate Economics, Vol. 25, pp. 615-630.

Brennan, M. and A. Subrahmanyam (1995), "Investment Analysis and Price Formation in Securities Markets", Journal of Financial Economics, Vol. 38, pp. 361-381.

Brinn, T., M. Peel and R. Roberts (1994), "Audit Fee Determinants of Independent \& Subsidiary Unquoted Companies in the UK--An Exploratory Study", British Accounting Review, Vol. 26, pp. 101-121.

Capozza, D. R. and P. J. Seguin (1999), "Focus, Transparency and Value: The REIT Evidence," Real Estate Economics, Vol. 27, pp. 587-619.

Chan, P., M. Ezzamel and D. Gwilliam (1993), "Determinants of Audit Fees for Quoted UK Companies", Journal of Business Finance and Accounting, Vol. 20, pp. 765-786.

Chung, K., B. Van Ness and R. Van Ness (2001), "Can the Treatment of Limit Orders Reconcile the Differences in Trading Costs Between NYSE and NASDAQ Issues?", Journal of Financial and Quantitative Analysis, Vol. 36, pp. 267-286.

Clayton, J. and G. MacKinnon (2000), "Measuring and Explaining Changes in REIT Liquidity: Moving Beyond the Bid-Ask Spread," Real Estate Economics, Vol. 28, pp. 89-115. 
Danielsen, B.R. and D. M. Harrison (2000), “The Impact of Potential Private Information on REIT Liquidity," Journal of Real Estate Research, Vol. 19, pp. 49-71.

Danielsen, B. R., R. A. Van Ness, and R. S. Warr (2007), “Auditor Fees, Market Microstructure, and Firm Transparency," Journal of Business Finance and Accounting, Vol. 34, pp. 202221.

Datar, S. M., G. A. Feltham and J. S. Hughes (1991), "The Role of Audits and Audit Quality in Valuing New Issues", Journal of Accounting and Economics, Vol. 14, pp. 3-49.

Demsetz, H. (1968), “The Cost of Transacting," Quarterly Journal of Economics, Vol. 82, pp. 33-53.

Ferguson, M., G. Seow and D. Young (2000), "The Effect of Non Audit Services on Audit Quality”, Working paper (University of Connecticut).

Firth, M., C. Liau-Tan (1998), “Auditor Quality, Signalling, and the Valuation of Initial Public Offerings", Journal of Business Finance and Accounting, Vol. 25, pp.145-165

Flannery M., S. Kwan and M. Nimalendran (2004), "Market Evidence on the Opaqueness of Banking Firms' Assets”, Journal of Financial Economics, Vol. 71, pp. 419-460.

Francis, J., T. Lys, and L. Vincent. "Valuation Effects of Debt and Equity Offerings by Real Estate Investment Trusts (REITs).” Working Paper, Northwestern University (2004).

Frankel R, M. Johnson and K. Nelson (2002), "The Relation Between Auditors' Fees for NonAudit Services and Earnings Management", The Accounting Review, Special Issue on Quality of Earnings, pp. 71-105, Supplement.

Garfinkel, J. and M. Nimalendran (2003), "Market Structure and Trader Anonymity: An Analysis of Insider Trading”, Journal of Financial and Quantitative Analysis, Vol. 38, pp. 591-610.

Glosten, L. R., and P. R. Milgrom, (1985), "Bid, Ask, and Transaction Prices in a Specialist Market with Heterogeneously Informed Traders," Journal of Financial Economics, Vol. 14, pp. 71-100.

Gore, G., P. Pope and A. Singh (2001), "Non-Audit Services, Auditor Independence, and Earnings Management”, Working paper (University of Lancaster).

Han, B. (2006), "Insider Ownership and Firm Value: Evidence from Real Estate Investment Trusts," Journal of Real Estate Finance and Economics, Vol. 32, pp. 471-493.

Hartzell, J. C., L. Sun and S. Titman (2006) "The Effect of Corporate Governance on Investment: Evidence from Real Estate Investment Trusts", Real Estate Economics, Vol 34, Issue 3, pp 343-376. 
Hartzell, J. C., J. G. Kallberg and C. H. Liu (2005) "The Role of the Underlying Real Asset Market in REIT IPOs", Real Estate Economics, Vol 33, Issue 1, pp 27-50.

Huang, R. and Stoll, H. (1996), "Dealer Versus Auction Markets: A Paired Comparison of Execution Costs on NASDAQ and the NYSE", Journal of Financial Economics, Vol. 41, pp. 313-357.

Kim, O., and R.E. Verrecchia, (1994), "Market liquidity and volume around earnings announcements", Journal of Accounting and Economics, Vol. 17, pp. 41-67.

Kim, O., and R. Verrecchia, (1997), "Pre-announcement and event period private information", Journal of Accounting and Economics, Vol.24, pp. 395-419.

Kyle, A. (1985), “Continuous Auctions and Insider Trading”, Econometrica, Vol. 53, pp. 13151336.

Lee. C. and M. Ready (1991), "Inferring Trade Direction from Intraday Data”, Journal of Finance, Vol. 46, pp. 733-746.

Lennox, C. (1990), “Audit Quality and Auditor Size: An Evaluation of Reputation and Deep Pockets Hypotheses”, Journal of Business Finance and Accounting, Vol. 26, pp 779-805.

Low, L., P. Tan and H. Koh (1990), "The Determination of Audit Fees: An Analysis in Singapore", Journal of Business Finance and Accounting, Vol. 17, pp. 285-295.

Lundholm, R. J., (1991), "Public signals and the equilibrium allocation of private information", Journal of Accounting Research, Vol. 29, pp. 322-349.

Marcato, G. and C. Ward (2007), "Back from Beyond the Bid-Ask Spread: Estimating Liquidity in International Markets," Real Estate Economics, Vol. 35, pp. 599-622.

McMeeking, K. P., K. V. Peasnell and P. F. Pope (2006), “The Determinants of the UK Big Firm Premium", Forthcoming Accounting and Business Research.

Myers, S. and N. Majluf (1984), "Corporate Investment and Financing Decisions When Firms Have Information That Investors Do Not Have", Journal of Financial Economics, Vol. 13, pp. 187-222.

O'Keefe, T., D. Simunic and M. Stein (1994), "The Production of Audit Services: Evidence from a Major Accounting Firm”, Journal of Accounting Research, Vol. 32, pp. 241-261.

Palmrose, Z-V. (1986), “Audit Fees and Auditor Size: Further Evidence”, Journal of Accounting Research, Vol. 24, pp. 97-110. 
Pong, C. and G. Whittington (1994), "The Determinants of Audit Fees: Some Empirical Models", Journal of Business Finance and Accounting, Vol. 21, pp. 1071-1095.

Rauterkus, S. and K. Song (2005), “Auditor's Reputation and Equity Offerings: The Case of Arthur Andersen”, Financial Management, Vol. 34, pp. 121-135.

SEC, 2000, "Revision of the Commission's Auditor Independence Requirements" Security and Exchange Commission, November: 33-7919.

Simunic, D. A. (1980), "The Price of Audit Services: Theory and Evidence", Journal of Accounting Research, Vol. 18, pp. 161-190.

Shockley, R. A. and R. N. Holt (1983), “A Behavioral Investigation of Supplier Differentiation on the Market for Audit Services", Journal of Accounting Research, Autumn, pp. 515-64.

Srinidhi, B. and F. Gul (2007), "The Differential Effects of Auditors' Nonaudit and Audit Fees on Accrual Quality", Contemporary Accounting Research, Volume 24, Number 2, pp. $595-629$.

Subrahmanyam, A. (2007) "Liquidity, Return and Order-Flow Linkages Between REITs and the Stock Market”, Real Estate Economics, Vol 35, Issue 3, pp 383-408.

Whisenant, S., S. Sankaraguruswamy and K. Raghunandan (2003), "Evidence on the Joint Determination of Audit and Non-Audit Fees", Journal of Accounting Research, Vol. 4, pp. 721-744. 
Table 1 REIT Market Auditors and Fees

\begin{tabular}{|c|c|c|c|c|}
\hline Audit Firm & \# of REIT Audits & $\begin{array}{c}\text { Average Audit } \\
\text { Fees }(\$, 000)\end{array}$ & $\begin{array}{c}\text { Minimum Audit } \\
\text { Fees }(\$, 000)\end{array}$ & $\begin{array}{c}\text { Maximum Audit } \\
\text { Fees }(\$, 000)\end{array}$ \\
\hline Ernst \& Young & 108 & 849.36 & 47.25 & $10,200.00$ \\
\hline PricewaterhouseCoopers & 66 & 521.22 & 86.50 & $2,017.67$ \\
\hline KPMG Peat Marwick & 62 & 700.99 & 75.00 & 4155.00 \\
\hline Deloitte \& Touche & 39 & 850.41 & 103.98 & $5,485.00$ \\
\hline Arthur Andersen & 15 & 444.16 & 42.50 & $2,600.00$ \\
\hline Grant Thornton & 5 & 282.88 & 182.50 & 462.60 \\
\hline BDO Seidman & 3 & 135.17 & 113.50 & 162.00 \\
\hline Other & 2 & 117.34 & 97.00 & 137.69 \\
\hline \multicolumn{5}{|c|}{ Panel B: Other Fee Characteristics } \\
\hline Audit Firm & \# of REIT Audits & $\begin{array}{c}\text { Average Other } \\
\text { Fees }(\$, 000)\end{array}$ & $\begin{array}{l}\text { Minimum Other } \\
\text { Fees }(\$, 000)\end{array}$ & $\begin{array}{l}\text { Maximum Other } \\
\text { Fees }(\$, 000)\end{array}$ \\
\hline Ernst \& Young & 108 & 240.37 & 0 & $10,700.00$ \\
\hline PricewaterhouseCoopers & 66 & 183.27 & 0 & $2,107.63$ \\
\hline KPMG Peat Marwick & 62 & 95.79 & 0 & $1,444.38$ \\
\hline Deloitte \& Touche & 39 & 267.45 & 0 & $3,458.00$ \\
\hline Arthur Andersen & 15 & 700.06 & 0 & $4,100.00$ \\
\hline Grant Thornton & 5 & 9.70 & 0 & 48.50 \\
\hline BDO Seidman & 3 & 46.07 & 0 & 138.22 \\
\hline Other & 2 & 1.85 & 0 & 3.70 \\
\hline \multicolumn{5}{|c|}{$\begin{array}{l}\text { Notes: Audit Fees are the fees recorded in the proxy statement as paid for audit services. Other fees are } \\
\text { all non-audit fee cash payments made from the auditee to their primary auditor in a given year. These fees } \\
\text { include, but are not limited to, payments for tax preparation and related services, as well as information } \\
\text { technology system development and support. }\end{array}$} \\
\hline
\end{tabular}


Table 2 REIT Market Auditors and Fees by Property Type Segment

\begin{tabular}{|c|c|c|c|c|c|}
\hline Property Type & $\begin{array}{c}\text { \# of } \\
\text { REITs }\end{array}$ & $\begin{array}{c}\text { Average Audit } \\
\text { Fees }(\$, 000)\end{array}$ & $\begin{array}{c}\text { Minimum Audit } \\
\text { Fees }(\$, 000)\end{array}$ & $\begin{array}{c}\text { Maximum Audit } \\
\text { Fees }(\$, 000)\end{array}$ & $\begin{array}{c}\text { Ratio of Audit } \\
\text { Fees to Other } \\
\text { Fees }\end{array}$ \\
\hline Unclassified & 13 & 305.88 & 71.00 & 922.95 & 1.30 \\
\hline Diversified & 24 & 842.72 & 47.25 & $5,485.00$ & 9.52 \\
\hline Health Care & 29 & 246.90 & 82.20 & 595.69 & 3.37 \\
\hline Industrial/Office & 66 & 704.17 & 77.00 & $4,100.30$ & 4.56 \\
\hline Lodging/Resorts & 23 & 953.43 & 42.50 & $6,200.00$ & 3.47 \\
\hline Mortgage & 23 & 627.14 & 86.50 & $1,903.50$ & 6.77 \\
\hline Residential & 47 & 935.22 & 113.70 & $10,200.00$ & 2.18 \\
\hline Retail & 72 & 737.50 & 85.00 & $4,155.00$ & 2.80 \\
\hline Self-Storage & 3 & 76.74 & 53.15 & 93.80 & 3.15 \\
\hline \multicolumn{6}{|c|}{ Panel B: Other Fee Characteristics } \\
\hline Property Type & $\begin{array}{c}\text { \# of } \\
\text { REITs }\end{array}$ & $\begin{array}{c}\text { Average Other } \\
\text { Fees }(\$, 000)\end{array}$ & $\begin{array}{c}\text { Minimum Other } \\
\text { Fees }(\$, 000)\end{array}$ & $\begin{array}{c}\text { Maximum Other } \\
\text { Fees }(\$, 000)\end{array}$ & $\begin{array}{c}\text { Ratio of Other } \\
\text { Fees to Audit } \\
\text { Fees }\end{array}$ \\
\hline Unclassified & 13 & 235.15 & 0 & $2,107.63$ & 0.77 \\
\hline Diversified & 24 & 88.55 & 0 & 858.00 & 0.11 \\
\hline Health Care & 29 & 73.16 & 0 & 561.77 & 0.30 \\
\hline Industrial/Office & 66 & 154.28 & 0 & 1444.38 & 0.22 \\
\hline Lodging/Resorts & 23 & 275.02 & 0 & 4100.00 & 0.29 \\
\hline Mortgage & 23 & 92.59 & 0 & 717.83 & 0.15 \\
\hline Residential & 47 & 429.12 & 0 & $10,700.00$ & 0.46 \\
\hline Retail & 72 & 262.97 & 0 & $3,458.00$ & 0.36 \\
\hline Self-Storage & 3 & 24.32 & 0 & 72.96 & 0.32 \\
\hline \multicolumn{6}{|c|}{$\begin{array}{l}\text { Notes: Audit Fees are the fees recorded in the proxy statement as paid for audit services. Other fees are all } \\
\text { non-audit fee cash payments made from the auditee to their primary auditor in a given year. These fees } \\
\text { include, but are not limited to, payments for tax preparation and related services, as well as information } \\
\text { technology system development and support. Property Type classifications are defined using the } \\
\text { CRSP/ZIMAN REIT data series for each firm year. Ratio of Audit Fees to Other Fees is the ratio of } \\
\text { Average Audit Fees to Average Other Fees. The Ratio of Other Fees to Audit Fees is the inverse. }\end{array}$} \\
\hline
\end{tabular}


Table 3 Summary Statistics

\begin{tabular}{|c|c|c|c|c|}
\hline & Mean & Std Deviation & Min & $\operatorname{Max}$ \\
\hline Market Value (\$Millions) & $1,684.48$ & $2,016.04$ & 19.87024 & $11,700.00$ \\
\hline Total Assets (\$Millions) & $2,858.77$ & $3,691.41$ & 45.549 & $25,808.42$ \\
\hline Employees $(, 000)$ & 1.74 & 10.97 & 0.00 & 115.00 \\
\hline Leverage & 0.65 & 0.16 & 0.06 & 1.24 \\
\hline Liquidity & 6.68 & 80.76 & 0.01 & 1397.01 \\
\hline$($ Inv. + Rec.)/Total Assets & 0.06 & 0.14 & 0.00 & 0.98 \\
\hline Return on Assets & 0.03 & 0.03 & -0.16 & 0.21 \\
\hline New Auditor & 0.25 & 0.44 & 0.00 & 1.00 \\
\hline Foreign Operations & 0.01 & 0.10 & 0.00 & 1.00 \\
\hline Net Loss Reported & 0.10 & 0.30 & 0.00 & 1.00 \\
\hline Growth Rate in Sales & 0.13 & 0.38 & -1.00 & 3.08 \\
\hline Qualified Opinion & 0.44 & 0.50 & 0.00 & 1.00 \\
\hline Pension Plan & 0.61 & 0.49 & 0.00 & 1.00 \\
\hline Book-to-Market Ratio & 0.81 & 0.19 & 0.27 & 1.47 \\
\hline Ext. Items or Disc. Ops. & 0.28 & 0.45 & 0.00 & 1.00 \\
\hline Restatements & 0.50 & 0.50 & 0.00 & 1.00 \\
\hline Equity REIT & 0.91 & 0.28 & 0.00 & 1.00 \\
\hline Mortgage REIT & 0.08 & 0.27 & 0.00 & 1.00 \\
\hline \multicolumn{5}{|c|}{ Panel B: Auditor Fee Characteristics } \\
\hline & Mean & Std Deviation & Min & $\operatorname{Max}$ \\
\hline Audit Fees & $704,918.90$ & $1,191,096.00$ & $42,500.00$ & $10,200,000.00$ \\
\hline Other Fees & $217,054.70$ & $759,991.70$ & 0.00 & $10,700,000.00$ \\
\hline \multicolumn{5}{|c|}{ Panel C: Market Microstructure Characteristics } \\
\hline & Mean & Std Deviation & Min & $\operatorname{Max}$ \\
\hline Quoted Spread \% & 0.37 & 0.59 & 0.05 & 4.99 \\
\hline Effective Spread\% & 0.24 & 0.41 & 0.03 & 3.38 \\
\hline Exchange = NYSE & 0.03 & 0.18 & 0.00 & 1.00 \\
\hline \multicolumn{5}{|c|}{$\begin{array}{l}\text { Notes: All firm level financial and operating characteristics represent fiscal year end values corresponding } \\
\text { to the year for which the reported Audit Fees and Other Fees were incurred. Panel B reports Audit Fees } \\
\text { and Other Fees. Audit Fees are the fees recorded in the proxy statement as paid for audit services, while } \\
\text { Other Fees are any cash payments from the auditee to the auditor for services other than directly auditing } \\
\text { the firm's financial statements. These services include primarily tax and information technology related } \\
\text { activities. Panel C presents microstructure characteristics of the sample firms for August of the year } \\
\text { immediately following the reported December financials and audit fees, a time period during which we } \\
\text { can be certain that the audit fees were known to the market as the proxy statements are released in the } \\
\text { spring of each year. Quoted Spread is the quoted spread divided by the midpoint price. Effective Spread } \\
\text { is the mean effective spread. Both spread measures are expressed as a percentage of the firm's stock } \\
\text { price. }\end{array}$} \\
\hline
\end{tabular}


Table 4 Correlations

\begin{tabular}{|c|c|c|c|c|c|c|c|c|c|c|c|}
\hline & Audit Fees & $\begin{array}{c}\text { Ab. Audit } \\
\text { Fees } \\
\text { (WSR) }\end{array}$ & $\begin{array}{l}\text { Rank } \\
\text { Audit } \\
\text { Fees }\end{array}$ & $\begin{array}{c}\text { Ab. Audit } \\
\text { Fees } \\
(D V W)\end{array}$ & $\begin{array}{l}\text { Other } \\
\text { Fees }\end{array}$ & $\begin{array}{c}\text { Ab. Other } \\
\text { Fees } \\
\text { (WSR) }\end{array}$ & $\begin{array}{l}\text { Rank } \\
\text { Other } \\
\text { Fees }\end{array}$ & $\begin{array}{c}\text { Ab. Other } \\
\text { Fees } \\
(D V W)\end{array}$ & $M V E$ & $\begin{array}{c}\text { Total } \\
\text { Assets }\end{array}$ & $\begin{array}{c}\% \\
\text { Quoted } \\
\text { Spread }\end{array}$ \\
\hline $\begin{array}{l}\text { Ab Audit Fee } \\
\text { (WSR) }\end{array}$ & $\begin{array}{l}0.4787 \\
(0.00)^{* * *}\end{array}$ & & & & & & & & & & \\
\hline Rank Audit Fees & $\begin{array}{c}0.5586 \\
(0.00)^{* *}\end{array}$ & $\begin{array}{l}0.55 \\
(0.00)^{* * *}\end{array}$ & & & & & & & & & \\
\hline $\begin{array}{l}\text { Ab. Audit Fees } \\
\text { (DVW) }\end{array}$ & $\begin{array}{l}0.6284 \\
(0.00)^{* * *}\end{array}$ & $\begin{array}{l}0.8336 \\
(0.00)^{* * *}\end{array}$ & $\begin{array}{c}0.6462 \\
(0.00)^{* * *}\end{array}$ & & & & & & & & \\
\hline Other Fees & $\begin{array}{l}0.2898 \\
(0.00)^{* * *}\end{array}$ & $\begin{array}{l}-0.0289 \\
(0.61)\end{array}$ & $\begin{array}{l}0.124 \\
(0.03)^{* *}\end{array}$ & $\begin{array}{l}0.0728 \\
(0.20)\end{array}$ & & & & & & & \\
\hline $\begin{array}{l}\text { Ab. Other Fees } \\
\text { (WSR) }\end{array}$ & $\begin{array}{l}-0.052 \\
(0.37)\end{array}$ & $\begin{array}{l}-0.2869 \\
(0.00)^{* * *}\end{array}$ & $\begin{array}{l}-0.204 \\
(0.00)^{* * *}\end{array}$ & $\begin{array}{l}-0.2392 \\
(0.00)^{* * *}\end{array}$ & $\begin{array}{l}0.3433 \\
(0.00)^{* * *}\end{array}$ & & & & & & \\
\hline Rank Other Fees & $\begin{array}{c}0.1197 \\
(0.03)^{* *}\end{array}$ & $\begin{array}{l}-0.2143 \\
(0.00)^{* * *}\end{array}$ & $\begin{array}{l}-0.071 \\
(0.21)\end{array}$ & $\begin{array}{l}-0.1215 \\
(0.03) * *\end{array}$ & $\begin{array}{l}0.4256 \\
(0.00)^{* * *}\end{array}$ & $\begin{array}{l}0.824 \\
(0.00)^{* * * *}\end{array}$ & & & & & \\
\hline $\begin{array}{l}\text { Ab. Other Fees } \\
(\mathrm{DVW})\end{array}$ & $\begin{array}{l}0.0696 \\
(0.23)\end{array}$ & $\begin{array}{l}-0.2489 \\
(0.00)^{* * *}\end{array}$ & $\begin{array}{l}-0.1879 \\
(0.00)^{* * *}\end{array}$ & $\begin{array}{l}-0.1608 \\
(0.00)^{* * *}\end{array}$ & $\begin{array}{l}0.4728 \\
(0.00)^{* * * *}\end{array}$ & $\begin{array}{l}0.8674 \\
(0.00)^{* * *}\end{array}$ & $\begin{array}{l}0.9319 \\
(0.00)^{* * * *}\end{array}$ & & & & \\
\hline $\begin{array}{l}\text { Market Value of } \\
\text { Equity }\end{array}$ & $\begin{array}{l}0.458 \\
(0.00)^{* * * *}\end{array}$ & $\begin{array}{l}-0.0419 \\
(0.47)\end{array}$ & $\begin{array}{l}0.5225 \\
(0.00)^{* * * *}\end{array}$ & $\begin{array}{c}0.1196 \\
(0.04)^{* *}\end{array}$ & $\begin{array}{l}0.1992 \\
(0.00)^{* * * *}\end{array}$ & $\begin{array}{l}-0.0395 \\
(0.49)\end{array}$ & $\begin{array}{l}0.0973 \\
(0.09)^{*}\end{array}$ & $\begin{array}{l}0.0376 \\
(0.51)\end{array}$ & & & \\
\hline Total Assets & $\begin{array}{l}0.4419 \\
(0.00)^{* * *}\end{array}$ & $\begin{array}{l}-0.0768 \\
(0.18)\end{array}$ & $\begin{array}{c}0.4623 \\
(0.00)^{* * * *}\end{array}$ & $\begin{array}{l}-0.0001 \\
(0.99)\end{array}$ & $\begin{array}{l}0.2174 \\
(0.00)^{* * * *}\end{array}$ & $\begin{array}{l}-0.0246 \\
(0.67)\end{array}$ & $\begin{array}{l}0.0858 \\
(0.13)\end{array}$ & $\begin{array}{l}0.0258 \\
(0.65)\end{array}$ & $\begin{array}{l}0.8157 \\
(0.00)^{* * *}\end{array}$ & & \\
\hline $\begin{array}{l}\text { Percentage Quoted } \\
\text { Spread }\end{array}$ & $\begin{array}{l}-0.1779 \\
(0.00)^{* * *}\end{array}$ & $\begin{array}{l}-0.0127 \\
(0.82)\end{array}$ & $\begin{array}{l}-0.303 \\
(0.00) * * *\end{array}$ & $\begin{array}{l}0.0001 \\
(0.99)\end{array}$ & $\begin{array}{l}-0.0573 \\
(0.31)\end{array}$ & $\begin{array}{l}0.0006 \\
(0.99)\end{array}$ & $\begin{array}{l}0.0521 \\
(0.36)\end{array}$ & $\begin{array}{l}0.0851 \\
(0.14)\end{array}$ & $\begin{array}{l}-0.2996 \\
(0.00)^{* * *}\end{array}$ & $\begin{array}{l}-0.2467 \\
(0.00)^{* * *}\end{array}$ & \\
\hline $\begin{array}{l}\text { Percentage Effective } \\
\text { Spread }\end{array}$ & $\begin{array}{l}-0.1723 \\
(0.00)^{* * *}\end{array}$ & $\begin{array}{l}-0.0357 \\
(0.53)\end{array}$ & $\begin{array}{l}-0.2788 \\
(0.00)^{* * *}\end{array}$ & $\begin{array}{l}-0.0173 \\
(0.76)\end{array}$ & $\begin{array}{l}-0.0376 \\
(0.51)\end{array}$ & $\begin{array}{l}0.0153 \\
(0.79)\end{array}$ & $\begin{array}{l}0.0852 \\
(0.13)\end{array}$ & $\begin{array}{l}0.1086 \\
(0.06)^{*}\end{array}$ & $\begin{array}{l}-0.2513 \\
(0.00)^{* * *}\end{array}$ & $\begin{array}{l}-0.2086 \\
(0.00)^{* * *}\end{array}$ & $\begin{array}{l}0.9798 \\
(0.00)^{* * *}\end{array}$ \\
\hline
\end{tabular}




\section{Table 4 continued}

Notes: Audit Fees are the raw audit fees paid by the REIT. Abnormal Audit Fees (WSR) are the residual from a regression of audit fees on their hypothesized determinants using the Whisenant, Sankaraguruswamy, and Raghunandan (2003) methodology. Rank Audit Fees are the percentile audit fee ranking paid to a specific auditor. Property Type Specific (or DVW) Abnormal Audit Fees are the residual from a regression of audit fees on the property type segment specific average audit fees, property type specific assets, and firm specific assets following the approach of Danielsen, Van Ness, and Warr (2007). Other Fees are payments made to auditor firms for services other than auditing a REIT's financial statements. These activities include tax and information technology related activities. Abnormal and Rank Other Fees calculations mirror the derivations for Audit Fees previously mentioned. Market Value of Equity and Total Assets are both measured as of the fiscal year end. Percentage Quoted Spread is the quoted bid-ask spread divided by the stock price. Percentage Effective Spread is the effective spread divided by the stock price. ***,**, and * indicates significant correlations at the $1 \%, 5 \%$, and $10 \%$ levels respectively. 
Table 5 Regressions of Spread Measures on Abnormal Audit Fees Paid by REITs

\begin{tabular}{|c|c|c|c|c|c|c|}
\hline \multirow{3}{*}{ Intercept } & \multicolumn{3}{|c|}{ In[Quoted Spread/Price] } & \multicolumn{3}{|c|}{ In[Effective Spread/Price] } \\
\hline & 0.990 & 0.731 & 0.991 & 0.474 & 0.045 & 0.488 \\
\hline & $(2.58)^{* *}$ & $(1.64)$ & $(2.56)^{* *}$ & $(0.93)$ & $(0.08)$ & $(0.95)$ \\
\hline \multirow[t]{2}{*}{ 1/[Number of Trades] } & 1.834 & 1.874 & 1.856 & 1.975 & 2.052 & 2.018 \\
\hline & $(4.79) * * *$ & $(4.70) * * *$ & $(4.67) * * *$ & $(3.93) * * *$ & $(3.83) * * *$ & $(3.77)^{* * *}$ \\
\hline \multirow[t]{2}{*}{ 1/[Trade Size] } & -42.579 & -46.753 & -42.779 & -90.026 & -95.395 & -93.485 \\
\hline & $(-1.69) *$ & $(-1.90)^{*}$ & $(-1.69) *$ & $(-3.30) * * *$ & $(-3.63) * * *$ & $(-3.38) * * *$ \\
\hline \multirow[t]{2}{*}{ Price } & -0.020 & -0.020 & -0.020 & -0.021 & -0.021 & -0.021 \\
\hline & $(-9.02)^{* * *}$ & $(-8.98)^{* * *}$ & $(-8.91)^{* * *}$ & $(-7.10) * * *$ & $(-6.97)^{* * *}$ & $(-6.96) * * *$ \\
\hline \multirow[t]{2}{*}{ 1/[SD of Quote Midpoint] } & -0.018 & -0.018 & -0.018 & -0.017 & -0.018 & -0.017 \\
\hline & $(-10.30) * * *$ & $(-10.79)^{* * *}$ & $(-10.59) * * *$ & $(-7.25)^{* * *}$ & $(-7.94)^{* * *}$ & $(-7.55) * * *$ \\
\hline \multirow[t]{2}{*}{ Number of Analysts } & -0.001 & -0.001 & -0.001 & -0.001 & -0.001 & -0.001 \\
\hline & $(-2.19) * *$ & $(-2.19) * *$ & $(-2.03) * *$ & $(-2.12)^{* *}$ & $(-2.08) * *$ & $(-1.92)^{*}$ \\
\hline \multirow[t]{2}{*}{ Abnorm Audit Fee (WSR) } & -0.050 & - & - & -0.103 & - & - \\
\hline & $(-1.71)^{*}$ & & & $(-2.55) * *$ & & \\
\hline \multirow[t]{2}{*}{ Rank Audit Fee } & - & -0.002 & - & - & -0.003 & - \\
\hline & & $(-2.06)^{* *}$ & & & $(-2.99) * * *$ & \\
\hline \multirow[t]{2}{*}{ Abnorm Audit Fee (DVW) } & - & - & -0.022 & - & - & -0.063 \\
\hline & & & $(-1.01)$ & & & $(-2.34) * *$ \\
\hline \multirow[t]{2}{*}{ Exchange } & 0.375 & 0.404 & 0.373 & 0.565 & 0.609 & 0.564 \\
\hline & $(3.53) * * *$ & $(3.71)^{* * *}$ & $(3.51)^{* * *}$ & $(4.87)^{* * *}$ & $(4.91)^{* * *}$ & $(4.77) * * *$ \\
\hline \multirow[t]{2}{*}{$\ln [\mathrm{MVE}]$} & -0.481 & -0.458 & -0.482 & -0.459 & -0.422 & -0.462 \\
\hline & $(-17.05) * * *$ & $(-13.60) * * *$ & $(-16.94) * * *$ & $(-10.66) * * *$ & $(-8.31)^{* * *}$ & $(-10.65)^{* * *}$ \\
\hline \multirow[t]{2}{*}{ Market-to-Book Ratio } & 0.075 & 0.072 & 0.083 & 0.046 & 0.039 & 0.071 \\
\hline & $(0.93)$ & $(0.88)$ & $(0.99)$ & $(0.58)$ & $(0.49)$ & $(0.86)$ \\
\hline$N$ & 300 & 300 & 300 & 300 & 300 & 300 \\
\hline$A d j, R^{2}$ & 0.8933 & 0.8936 & 0.8923 & 0.8565 & 0.8555 & 0.8540 \\
\hline$F(17,282)$ & 151.11 & 143.92 & 143.69 & 161.40 & 145.10 & 152.49 \\
\hline Prob. > F & 0.0000 & 0.0000 & 0.0000 & 0.0000 & 0.0000 & 0.0000 \\
\hline
\end{tabular}




\section{Table 5 Continued}

Notes: The dependent variables are either the natural log of the quoted spread or the effective spread as a percentage of the price. Number of Trades is the average daily number of trades for the stock, Trade size is the average daily size of trade, and SD of Quote Midpoint is the average daily standard deviation of the intra day quote mid point. Number of Analysts is from I/B/E/S-FirstCall. Abnormal Audit Fees (WSR) are the residual of a regression of Audit Fees on a vector of firm specific characteristics believed to be their major determinants. Rank Audit Fee is the percentile rank of the audit fee paid to a specific auditor. Abnormal Audit Fee (DVW) is the residual of a regression of audit fees on industry assets, firm assets, and industry audit fees. Exchange is a dummy variable which takes the value of 1 for NASDAQ stocks and 0 for NYSE stocks. $\ln [\mathrm{MVE}]$ is the $\log$ of the market value of equity, while Market-to-Book is the ratio of the market value of the firm's assets to their book value. All regressions include unreported REIT property fixed effects. White corrected t-statistics are in parenthesis. ***,*** indicates significance at the $1 \%, 5 \%$, and $10 \%$ levels respectively. 
Table 6 Regressions of Spread Measures on Abnormal Other Fees Paid by REITs

\begin{tabular}{|c|c|c|c|c|c|c|}
\hline \multirow{3}{*}{ Intercept } & \multicolumn{3}{|c|}{ In[Quoted Spread/Price] } & \multicolumn{3}{|c|}{ In[Effective Spread/Price] } \\
\hline & 0.870 & 0.728 & 0.694 & 0.297 & 0.045 & 0.024 \\
\hline & $(2.19)^{* *}$ & $(1.74)^{*}$ & $(1.69)^{*}$ & $(0.56)$ & $(0.08)$ & $(0.04)$ \\
\hline \multirow[t]{2}{*}{ 1/[Number of Trades] } & 1.865 & 1.817 & 1.821 & 2.037 & 1.960 & 1.970 \\
\hline & $(5.07)^{* * *}$ & $(5.06)^{* * *}$ & $(5.16)^{* * *}$ & $(4.15)^{* * *}$ & $(4.18) * * *$ & $(4.24) * * *$ \\
\hline \multirow[t]{2}{*}{ 1/[Trade Size] } & -27.055 & -14.163 & -6.347 & -65.584 & -42.330 & -33.682 \\
\hline & $(-1.04)$ & $(-0.53)$ & $(-0.23)$ & $(-2.39)^{* *}$ & $(-1.48)$ & $(-1.17)$ \\
\hline \multirow[t]{2}{*}{ Price } & -0.021 & -0.021 & -0.021 & -0.021 & -0.022 & -0.022 \\
\hline & $(-9.18)^{* * *}$ & $(-9.27)^{* * *}$ & $(-9.45)^{* * *}$ & $(-7.08)^{* * *}$ & $(-7.16)^{* * *}$ & $(-7.29)^{* * *}$ \\
\hline \multirow[t]{2}{*}{ 1/[SD of Quote Midpoint] } & -0.017 & -0.017 & -0.016 & -0.016 & -0.016 & -0.015 \\
\hline & $(-9.95)^{* * *}$ & $(-10.23)^{* * *}$ & $(-9.69) * * *$ & $(-7.21)^{* * *}$ & $(-7.95)^{* * *}$ & $(-7.85)^{* * *}$ \\
\hline \multirow[t]{2}{*}{ Number of Analysts } & -0.001 & -0.001 & -0.001 & -0.001 & -0.001 & -0.001 \\
\hline & $(-2.18)^{* *}$ & $(-2.11)^{* *}$ & $(-2.13)^{* *}$ & $(-2.07)^{* *}$ & $(-2.01)^{* *}$ & $(-2.03)^{* *}$ \\
\hline \multirow[t]{2}{*}{ Ab. Other Fee (WSR) } & 0.018 & - & - & 0.025 & - & - \\
\hline & $(2.30) * *$ & & & $(3.14)^{* * *}$ & & \\
\hline \multirow[t]{2}{*}{ Rank Other Fee } & - & 0.002 & - & - & 0.003 & - \\
\hline & & $(2.75) * * *$ & & & $(3.49) * * *$ & \\
\hline \multirow[t]{2}{*}{ Ab. Other Fee (DVW) } & - & - & 0.024 & - & - & $\mathbf{0 . 0 3 7}$ \\
\hline & & & $(3.46) * * *$ & & & $(4.06)^{* * *}$ \\
\hline \multirow[t]{2}{*}{ Exchange } & 0.388 & 0.380 & 0.396 & 0.580 & 0.570 & 0.593 \\
\hline & $(3.59)^{* * *}$ & $(3.59)^{* * *}$ & $(3.74) * * *$ & $(4.86)^{* * *}$ & $(5.05)^{* * *}$ & $(5.10) * * *$ \\
\hline \multirow[t]{2}{*}{$\ln [\mathrm{MVE}]$} & -0.476 & -0.475 & -0.468 & -0.452 & -0.449 & -0.439 \\
\hline & $(-16.51)^{* * *}$ & $(-16.50)^{* * *}$ & $(-16.10)^{* * *}$ & $(-10.08)^{* * *}$ & $(-10.00)^{* * *}$ & $(-9.57)^{* * *}$ \\
\hline \multirow[t]{2}{*}{ Market-to-Book Ratio } & 0.072 & 0.084 & 0.085 & 0.037 & 0.057 & 0.057 \\
\hline & $(0.94)$ & $(1.07)$ & $(1.09)$ & $(0.52)$ & $(0.79)$ & $(0.78)$ \\
\hline$N$ & 300 & 300 & 300 & 300 & 300 & 300 \\
\hline Adj, $R^{2}$ & 0.8943 & 0.8952 & 0.8970 & 0.8558 & 0.8595 & 0.8621 \\
\hline$F(17,282)$ & 147.13 & 146.82 & 152.27 & 152.58 & 160.03 & 162.37 \\
\hline Prob. $>F$ & 0.0000 & 0.0000 & 0.0000 & 0.0000 & 0.0000 & 0.0000 \\
\hline
\end{tabular}




\section{Table 6 Continued}

Notes: The dependent variables are either the natural log of the quoted spread or the effective spread as a percentage of the price. Number of Trades is the average daily number of trades for the stock, Trade size is the average daily size of trade, and SD of Quote Midpoint is the average daily standard deviation of the intra day quote mid point. Number of Analysts is from I/B/E/S-FirstCall. Abnormal Other Fees (WSR) are the residual of a regression of Other Fees on a vector of firm specific characteristics believed to be their major determinants. Rank Other Fees are the percentile rank of the other fees paid to a specific auditor. Abnormal Other Fees (DVW) are the residual of a regression of other fees on industry assets, firm assets and industry other fees. Exchange is a dummy variable which takes the value of 1 for NASDAQ stocks and 0 for NYSE stocks. $\ln [\mathrm{MVE}]$ is the $\log$ of market value of equity, while Market-to-Book is the ratio of the market value of the firm's assets to their book value. All regressions include unreported REIT property fixed effects. White corrected t-statistics are in parenthesis. $* * *, * *, *$ indicates significance at the $1 \%, 5 \%$, and $10 \%$ levels respectively. 
Table 7 Regressions of Spread Measures on Both Abnormal Audit Fees \& Abnornal Other Fees Paid by REITs

\begin{tabular}{|c|c|c|c|c|c|c|}
\hline & \multicolumn{3}{|c|}{ In[Quoted Spread/Price] } & \multicolumn{3}{|c|}{ In[Effective Spread/Price] } \\
\hline & $\underline{\text { WSR }}$ & $\underline{\text { RANK }}$ & $\underline{\text { DVW }}$ & WSR & RANK & $\underline{\text { DVW }}$ \\
\hline \multirow[t]{2}{*}{ Intercept } & 0.894 & 0.566 & 0.698 & 0.355 & -0.222 & 0.072 \\
\hline & $(2.29)^{* *}$ & $(1.24)$ & $(1.71)^{*}$ & $(0.70)$ & $(-0.36)$ & $(0.13)$ \\
\hline \multirow[t]{2}{*}{ 1/[Number of Trades] } & 1.848 & 1.832 & 1.820 & 1.993 & 1.985 & 1.968 \\
\hline & $(5.09) * * *$ & $(5.01)^{* * *}$ & $(5.14) * * *$ & $(4.17)^{* * *}$ & $(4.14) * * *$ & $(4.17)^{* * *}$ \\
\hline \multirow[t]{2}{*}{ 1/[Trade Size] } & -31.152 & -22.542 & -7.251 & -75.784 & -56.125 & -43.023 \\
\hline & $(-1.18)$ & $(-0.85)$ & $(-0.26)$ & $(-2.63) * * *$ & $(-1.99) * *$ & $(-1.44)$ \\
\hline \multirow[t]{2}{*}{ Price } & -0.020 & -0.021 & -0.021 & -0.021 & -0.022 & -0.022 \\
\hline & $(-9.24)^{* * *}$ & $(-9.31)^{* * *}$ & $(-9.48)^{* * *}$ & $(-7.26)^{* * *}$ & $(-7.20)^{* * *}$ & $(-7.37)^{* * *}$ \\
\hline \multirow[t]{2}{*}{ 1/[SD of Quote Midpoint] } & -0.017 & -0.017 & -0.016 & -0.016 & -0.016 & -0.015 \\
\hline & $(-9.85)^{* * *}$ & $(-10.26) * * *$ & $(-9.66)^{* * *}$ & $(-7.19) * * *$ & $(-8.46) * * *$ & $(-7.97)^{* * *}$ \\
\hline \multirow[t]{2}{*}{ Number of Analysts } & -0.001 & -0.001 & -0.001 & -0.001 & -0.001 & -0.001 \\
\hline & $(-2.26)^{* *}$ & $(-2.23) * *$ & $(-2.13) * *$ & $(-2.19) * *$ & $(-2.15)^{* *}$ & $(-2.03) * *$ \\
\hline \multirow[t]{2}{*}{ Abnormal Audit Fees } & -0.033 & -0.001 & -0.004 & -0.081 & -0.002 & $-\mathbf{0 . 0 3 7}$ \\
\hline & $(-1.11)$ & $(-1.56)$ & $(-0.16)$ & $(-1.93)^{*}$ & $(-2.41)^{* *}$ & $(-1.43)$ \\
\hline \multirow[t]{2}{*}{ Abnormal Other Fees } & 0.015 & 0.002 & 0.024 & 0.019 & 0.003 & 0.034 \\
\hline & $(1.93)^{*}$ & $(2.49) * *$ & $(3.36) * * *$ & $(2.25)^{* *}$ & $(3.23) * * *$ & $(3.93)^{* * *}$ \\
\hline \multirow[t]{2}{*}{ Exchange } & 0.389 & 0.405 & 0.397 & 0.582 & 0.611 & 0.597 \\
\hline & $(3.60)^{* * *}$ & $(3.75)^{* * *}$ & $(3.72)^{* * *}$ & $(4.96)^{* * *}$ & $(5.19)^{* * *}$ & $(5.08) * * *$ \\
\hline \multirow[t]{2}{*}{$\ln [\mathrm{MVE}]$} & -0.477 & -0.459 & -0.468 & -0.454 & -0.423 & -0.443 \\
\hline & $(-16.94) * * *$ & $(-13.94) * * *$ & $(-16.23) * * *$ & $(-10.65) * * *$ & $(-8.62) * * *$ & $(-9.93) * * *$ \\
\hline \multirow[t]{2}{*}{ Market-to-Book Ratio } & 0.075 & 0.084 & 0.087 & 0.045 & 0.058 & 0.077 \\
\hline & $(0.96)$ & $(1.04)$ & $(1.08)$ & $(0.60)$ & $(0.75)$ & $(0.97)$ \\
\hline$N$ & 300 & 300 & 300 & 300 & 300 & 300 \\
\hline$A d j, R^{2}$ & 0.8948 & 0.8961 & 0.8971 & 0.8587 & 0.8618 & 0.8629 \\
\hline$F(18,281)$ & 143.55 & 142.23 & 145.32 & 149.67 & 151.97 & 151.90 \\
\hline Prob. $>F$ & 0.0000 & 0.0000 & 0.0000 & 0.0000 & 0.0000 & 0.0000 \\
\hline
\end{tabular}




\section{Table 7 Continued}

Notes: The dependent variables are either the natural log of the quoted spread or the effective spread as a percentage of the price. Number of Trades is the average daily number of trades for the stock, Trade size is the average daily size of trade, and SD of Quote Midpoint is the average daily standard deviation of the intra day quote mid point. Number of Analysts is from I/B/E/S-FirstCall. Abnormal Audit Fees (WSR) are the residual of a regression of Audit Fees on a vector of firm specific characteristics believed to be their major determinants. Rank Audit Fee is the percentile rank of the audit fee paid to a specific auditor. Abnormal Audit Fee (DVW) is the residual of a regression of audit fees on industry assets, firm assets, and industry audit fees. Exchange is a dummy variable which takes the value of 1 for NASDAQ stocks and 0 for NYSE stocks. $\ln [\mathrm{MVE}]$ is the log of the market value of equity, while Market-to-Book is the ratio of the market value of the firm's assets to their book value. All regressions include unreported REIT property fixed effects. White corrected t-statistics are in parenthesis. ***,**,* indicates significance at the $1 \%, 5 \%$, and $10 \%$ levels respectively. 
Table 8 Regressions of Changes in Effective Spread Measures on Changes in Abnormal Audit Fees Paid by REITs

\begin{tabular}{|c|c|c|c|c|c|c|}
\hline \multirow{3}{*}{ Intercept } & \multicolumn{3}{|c|}{ Audit Fees: In[Effective Spread/Price] } & \multicolumn{3}{|c|}{ Other Fees: In[Effective Spread/Price] } \\
\hline & -0.225 & -0.234 & -0.215 & -0.208 & -0.213 & -0.193 \\
\hline & $(-4.85)^{* * *}$ & $(-4.85)^{* * *}$ & $(-4.67) * * *$ & $(-4.69) * * *$ & $(-4.77) * * *$ & $(-4.27) * * *$ \\
\hline \multirow[t]{2}{*}{$\Delta 1 /[$ Number of Trades $]$} & 1.626 & 1.580 & 1.513 & 1.636 & 1.676 & 1.702 \\
\hline & $(11.92)^{* * *}$ & $(11.44)^{* * *}$ & $(11.06)^{* * *}$ & $(11.59)^{* * *}$ & $(11.45)^{* * *}$ & $(11.79)^{* * *}$ \\
\hline \multirow[t]{2}{*}{$\Delta 1 /[$ Trade Size $]$} & 26.631 & 25.027 & 25.222 & 30.403 & 29.674 & 32.237 \\
\hline & $(0.73)$ & $(0.68)$ & $(0.69)$ & $(0.86)$ & $(0.84)$ & $(0.90)$ \\
\hline \multirow[t]{2}{*}{$\Delta$ Price } & -0.012 & -0.012 & -0.011 & -0.010 & -0.010 & -0.010 \\
\hline & $(-2.69) * * *$ & $(-2.67)^{* * *}$ & $(-2.66)^{* * * *}$ & $(-2.35) * *$ & $(-2.16) * *$ & $(-2.25) * *$ \\
\hline \multirow[t]{2}{*}{$\Delta 1 /[$ SD of Quote $]$} & -0.016 & -0.016 & -0.016 & -0.016 & -0.016 & -0.016 \\
\hline & $(-5.32) * * *$ & $(-5.32) * * *$ & $(-5.37) * * *$ & $(-5.19) * * *$ & $(-5.34) * * *$ & $(-5.47) * * *$ \\
\hline \multirow[t]{2}{*}{$\Delta$ Number of Analysts } & 0.001 & 0.001 & 0.001 & 0.002 & 0.002 & 0.002 \\
\hline & $(0.90)$ & $(0.98)$ & $(0.90)$ & $(1.14)$ & $(1.24)$ & $(1.27)$ \\
\hline \multirow[t]{2}{*}{$\Delta$ Abnormal Fee (WSR) } & -0.102 & - & - & 0.022 & - & - \\
\hline & $(-2.39)^{* *}$ & & & $(2.82)^{* * *}$ & & \\
\hline \multirow[t]{2}{*}{$\Delta$ Rank Fee } & - & -0.002 & - & - & 0.002 & - \\
\hline & & $(-2.23)^{* *}$ & & & $(2.42)^{* *}$ & \\
\hline \multirow[t]{2}{*}{$\Delta$ Abnormal Fee (DVW) } & - & - & -0.108 & - & - & 0.024 \\
\hline & & & $(-2.46)^{* *}$ & & & $(2.98) * * *$ \\
\hline \multirow[t]{2}{*}{$\Delta \mathrm{Ln}[\mathrm{MVE}]$} & -0.321 & -0.280 & -0.336 & -0.379 & -0.372 & -0.383 \\
\hline & $(-2.27) * *$ & $(-1.89)^{*}$ & $(-2.43) * *$ & $(-2.81)^{* * *}$ & $(-2.72)^{* * *}$ & $(-2.79) * * *$ \\
\hline \multirow[t]{2}{*}{$\Delta$ Market-to-Book Ratio } & 0.060 & 0.081 & 0.107 & 0.083 & 0.112 & 0.084 \\
\hline & $(0.43)$ & $(0.61)$ & $(0.73)$ & $(0.63)$ & $(0.89)$ & $(0.63)$ \\
\hline$N$ & 181 & 184 & 181 & 181 & 184 & 181 \\
\hline$A d j, R^{2}$ & 0.2953 & 0.2866 & 0.2970 & 0.3066 & 0.2965 & 0.3087 \\
\hline$F(8, N-9)$ & 49.57 & 45.82 & 54.07 & 47.45 & 44.59 & 47.85 \\
\hline Prob. $>F$ & 0.0000 & 0.0000 & 0.0000 & 0.0000 & 0.0000 & 0.0000 \\
\hline
\end{tabular}




\section{Table 8 continued}

Notes: The dependent variables are either the natural log of the quoted spread or the effective spread as a percentage of the price. Number of Trades is the average daily number of trades for the stock, Trade size is the average daily size of trade, and SD of Quote Midpoint is the average daily standard deviation of the intra day quote mid point. Number of Analysts is from I/B/E/S-FirstCall. Abnormal Audit Fees (WSR) are the residual of a regression of Audit Fees on a vector of firm specific characteristics believed to be their major determinants. Rank Audit Fee is the percentile rank of the audit fee paid to a specific auditor. Abnormal Audit Fee (DVW) is the residual of a regression of audit fees on industry assets, firm assets, and industry audit fees. Exchange is a dummy variable which takes the value of 1 for NASDAQ stocks and 0 for NYSE stocks. $\ln [\mathrm{MVE}]$ is the $\log$ of the market value of equity, while Market-to-Book is the ratio of the market value of the firm's assets to their book value. White corrected t-statistics are in parenthesis. ***,**,* indicates significance at the $1 \%, 5 \%$, and $10 \%$ levels respectively. 
Table 9 Regressions of Effective Spread Measures on Abnormal Audit Fees Paid by all December Year-end Firms

\begin{tabular}{|c|c|c|c|c|c|c|}
\hline & \multicolumn{3}{|c|}{ Audit Fees: In[Effective Spread/Price] } & \multicolumn{3}{|c|}{ Other Fees: In[Effective Spread/Price] } \\
\hline & $\underline{\text { WSR }}$ & $\underline{\text { RANK }}$ & $\underline{\mathrm{DVW}}$ & $\underline{\mathrm{WSR}}$ & $\underline{\text { RANK }}$ & $\underline{\text { DVW }}$ \\
\hline \multirow[t]{2}{*}{ Intercept } & 0.137 & 0.107 & 0.019 & 0.099 & 0.066 & -0.008 \\
\hline & $(1.03)$ & $(0.79)$ & $(0.15)$ & $(0.75)$ & $(0.49)$ & $(-0.06)$ \\
\hline \multirow[t]{2}{*}{ 1/[Number of Trades] } & 2.863 & 3.200 & 2.903 & 2.858 & 2.887 & 2.863 \\
\hline & $(15.67)^{* * *}$ & $(13.93)^{* * *}$ & $(16.71)^{* * *}$ & $(15.72)^{* * *}$ & $(14.79)^{* * *}$ & $(16.50)^{* * *}$ \\
\hline \multirow[t]{2}{*}{ 1/[Trade Size] } & -122.580 & -139.822 & -110.328 & -113.017 & -113.659 & -100.093 \\
\hline & $(-12.67)^{* * *}$ & $(-14.02) * * *$ & $(-11.58) * * *$ & $(-11.67)^{* * *}$ & $(-11.60) * * *$ & $(-10.49) * * *$ \\
\hline \multirow[t]{2}{*}{ Price } & -0.001 & -0.001 & -0.002 & -0.001 & -0.001 & -0.002 \\
\hline & $(-1.14)$ & $(-0.93)$ & $(-1.44)$ & $(-1.17)$ & $(-1.14)$ & $(-1.45)$ \\
\hline \multirow[t]{2}{*}{ 1/[SD of Quote Midpoint] } & 0.000 & 0.000 & 0.000 & 0.000 & 0.000 & 0.000 \\
\hline & $(0.56)$ & $(0.13)$ & $(0.73)$ & $(0.79)$ & $(0.78)$ & $(1.00)$ \\
\hline \multirow[t]{2}{*}{ Number of Analysts } & -0.001 & -0.001 & -0.001 & -0.001 & -0.001 & -0.001 \\
\hline & $(-4.20)^{* * *}$ & $(-4.17) * * *$ & $(-4.36)^{* * *}$ & $(-4.04) * * *$ & $(-4.15)^{* * *}$ & $(-4.19) * * *$ \\
\hline \multirow[t]{2}{*}{ Abnorm Audit or Other Fee } & -0.017 & -0.003 & -0.002 & $\mathbf{0 . 0 3 7}$ & 0.003 & 0.042 \\
\hline & $(-1.47)$ & $(-5.44)^{* * * *}$ & $(-0.18)$ & $(11.42)^{* * *}$ & $(11.58)^{* * *}$ & $(13.85)^{* * *}$ \\
\hline \multirow[t]{2}{*}{ Abnormal Fee * REIT } & -0.101 & -0.001 & -0.093 & -0.008 & -0.001 & -0.009 \\
\hline & $(-2.27)^{* *}$ & $(-1.41)$ & $(-2.98)^{* * *}$ & $(-0.83)$ & $(-0.87)$ & $(-0.86)$ \\
\hline \multirow[t]{2}{*}{ REIT Indicator } & 0.096 & 0.100 & 0.093 & 0.101 & 0.164 & 0.093 \\
\hline & $(3.16) * * *$ & $(1.75) *$ & $(3.07) * * *$ & $(3.32) * * *$ & $(3.01)^{* * *}$ & $(3.12) * * *$ \\
\hline \multirow[t]{2}{*}{ Exchange } & 0.319 & 0.303 & 0.320 & 0.321 & 0.325 & 0.320 \\
\hline & $(31.25)^{* * *}$ & $(29.75)^{* * *}$ & $(32.54) * * *$ & $(31.88)^{* * *}$ & $(32.67)^{* * *}$ & $(33.04)^{* * *}$ \\
\hline \multirow[t]{2}{*}{$\ln [\mathrm{MVE}]$} & -0.471 & -0.453 & -0.464 & -0.470 & -0.482 & -0.464 \\
\hline & $(-44.82) * * *$ & $(-39.22) * * *$ & $(-45.28) * * *$ & $(-44.84) * * *$ & $(-45.60) * * *$ & $(-45.19) * * *$ \\
\hline \multirow[t]{2}{*}{ Market-to-Book Ratio } & -0.009 & -0.013 & -0.007 & -0.009 & -0.005 & -0.007 \\
\hline & $(-1.45)$ & $(-1.66)^{*}$ & $(-1.45)$ & $(-1.53)$ & $(-1.01)$ & $(-1.45)$ \\
\hline$N$ & 6,248 & 5,966 & 6,747 & 6,248 & 6,155 & 6,747 \\
\hline$A d j, R^{2}$ & 0.8203 & 0.8195 & 0.8164 & 0.8243 & 0.8223 & 0.8221 \\
\hline$F(11, N-12)$ & $2,106.97$ & $2,061.10$ & $2,208.05$ & $2,129.61$ & $2,119.35$ & $2,338.42$ \\
\hline Prob. $>F$ & 0.000 & 0.0000 & 0.0000 & 0.0000 & 0.0000 & 0.0000 \\
\hline
\end{tabular}




\section{Table 9 continued}

Notes: The dependent variables are either the natural log of the quoted spread or the effective spread as a percentage of the price. Number of Trades is the average daily number of trades for the stock, Trade size is the average daily size of trade, and SD of Quote Midpoint is the average daily standard deviation of the intra day quote mid point. Number of Analysts is from I/B/E/S-FirstCall. Abnormal Audit Fees (WSR) are the residual of a regression of Audit Fees on a vector of firm specific characteristics believed to be their major determinants. Rank Audit Fee is the percentile rank of the audit fee paid to a specific auditor. Abnormal Audit Fee (DVW) is the residual of a regression of audit fees on industry assets, firm assets, and industry audit fees. Exchange is a dummy variable which takes the value of 1 for NASDAQ stocks and 0 for NYSE stocks. $\ln [\mathrm{MVE}]$ is the $\log$ of the market value of equity, while Market-to-Book is the ratio of the market value of the firm's assets to their book value. White corrected t-statistics are in parenthesis. ***,**,* indicates significance at the $1 \%, 5 \%$, and $10 \%$ levels respectively. 